\title{
A PREFEASIBILITY STUDY OF ENERGY RESOURCE OPTIONS IN HAINAN, CHINA
}

\author{
Lawrence J. Hill \\ Oak Ridge National Laboratory \\ William F. Barron \\ University of Hong Kong \\ Phil LaRocco \\ LaRocco Associates \\ Milton Russell \\ University of Tennesee/ \\ Oak Ridge National Laboratory \\ Zhongmin Shen \\ University of Tennessee
}

Date Published: October 1992

Prepared for

Office of Conservation and Renewable Energy

U.S. DEPARTMENT OF ENERGY

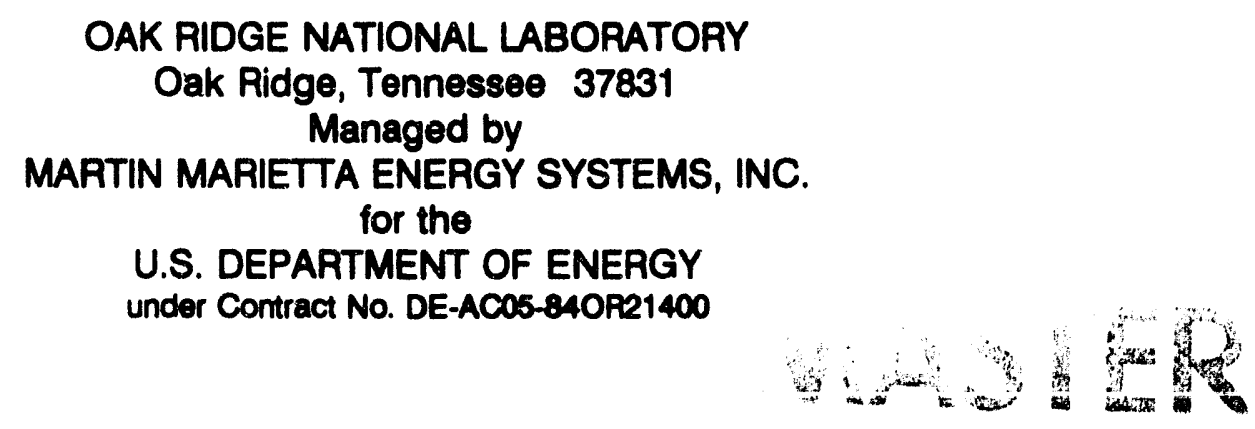




\section{CONTENTS}

LIST OF FIGURES AND TABLES $\ldots \ldots \ldots \ldots \ldots \ldots \ldots \ldots \ldots$

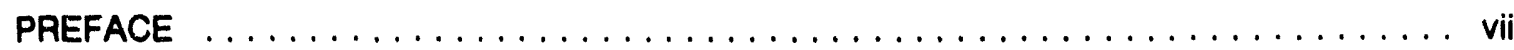

INTRODUCTION AND EXECUTIVE SUMMARY $\ldots \ldots \ldots \ldots \ldots \ldots \ldots$

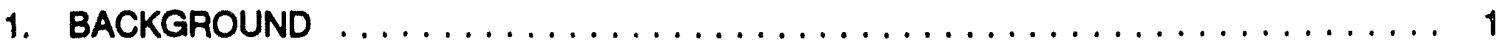

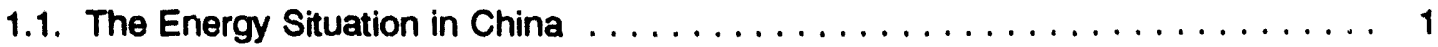

1.2. What is Integrated Resource Planning? $\ldots \ldots \ldots \ldots \ldots \ldots \ldots \ldots$

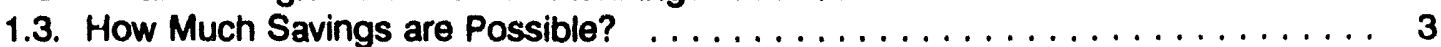

1.4. Scope and Organization of the Study $\ldots \ldots \ldots \ldots \ldots \ldots \ldots$

2. OVERVIEW OF HAINAN $\ldots \ldots \ldots \ldots \ldots \ldots \ldots \ldots \ldots \ldots \ldots$

2.1. Background on Hainan's Economy $\ldots \ldots \ldots \ldots \ldots \ldots \ldots \ldots \ldots \ldots$

2.2. An Overview of the Energy Sector . . . . . . . . . . . . . . . . . . . . . . 10

2.2.1. Energy Balance . . . . . . . . . . . . . . . . . . . . . . 10

2.2.2. A Closer Look at the Power Sector . . . . . . . . . . . . . . . . . . . 10

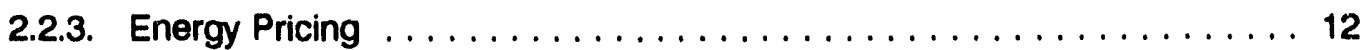

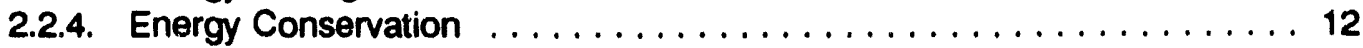

3. AN INDICATION OF POSSIBLE SAVINGS FROM IRP . . . . . . . . . . . . . . 15

3.1. Procedures for Determining Cost-Effective Options . . . . . . . . . . . . . 15

3.2. Application Used in this Study . . . . . . . . . . . . . . . . . . . . . 18

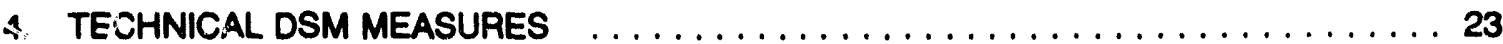

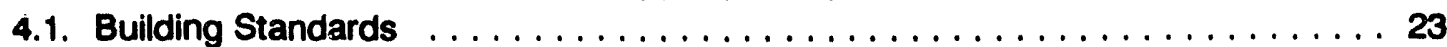

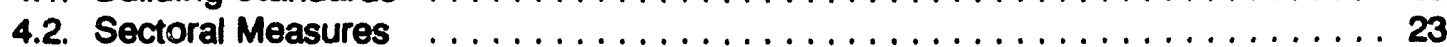

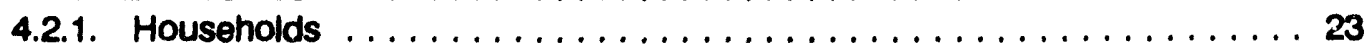

4.2.2. Commerce ............................ 24

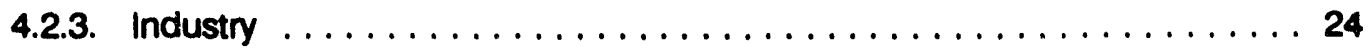

4.2.4. Transportation $\ldots \ldots \ldots \ldots \ldots \ldots \ldots$

5. A BEHAVIORAL DSM STRATEGY: ELECTRICITY PRICING . . . . . . . . . . . . . . 27

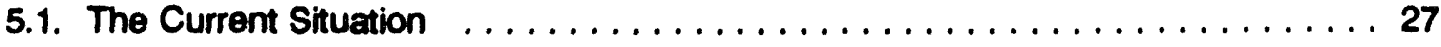

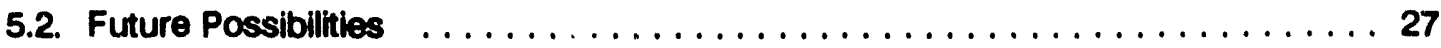

6. RENEWABLE RESOURCE OPTIONS $\ldots \ldots \ldots \ldots \ldots \ldots \ldots \ldots \ldots \ldots$

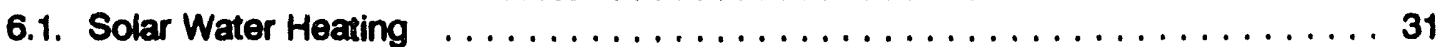

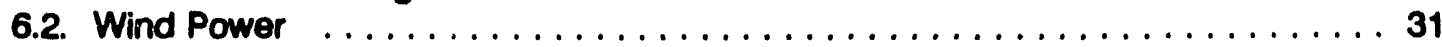

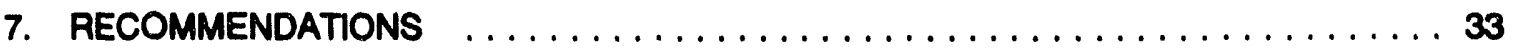

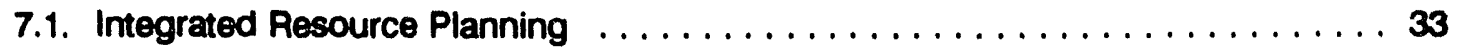

7.1.1. Training ........................... 33

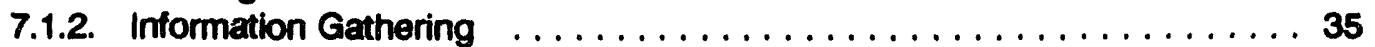

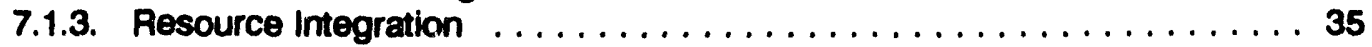

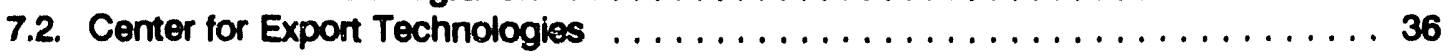

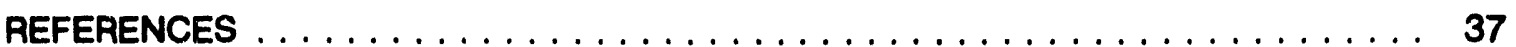




\section{UST OF FIGURES AND TABLES}

Figure

Description

Page

1 Integrated Resource Planning as Part of a Dynamic Process . . . . . 2

2 Incremental and Total DSM and Supply Resources $\ldots \ldots \ldots \ldots$

3 DSM Contributions to Resource Additions, Utility Survey $\ldots \ldots \ldots \ldots$

4 Cost-Effective DSM Options $\ldots \ldots \ldots \ldots \ldots \ldots \ldots \ldots$

Table

Description

Page

S.1 Summary of Potential Savings, Demand-Side Management

Measures, Hainan, China, $2000 \ldots \ldots \ldots \ldots \ldots \ldots$ xi

1 Estimated Energy and Peak Load Savings from DSM programs,

U.S. Electric Utilities, 1990 and $2000 \ldots \ldots \ldots \ldots$

2 Actual and Projected Population and GDP, Hainan, China,

1990,1995, and $2000 \ldots \ldots \ldots 10 \ldots \ldots$

3 Actual and Projected Growth of Generating Capacity, Hainan,

China Provincial Grid, 1992, 1995, and $2000 \ldots \ldots \ldots 11$

4 Actual and Projected Growth in Electricity Consumption,

Hainan, China, 1990, 1995, and $2000 \ldots \ldots \ldots \ldots 12$

$5 \quad$ Indication of Possible Energy Savings from Conservation

Programs, By Consuming Sector, Hainan, China, $2000 \ldots 21$

6 Current Electricity Tariffs, Hainan, China . . . . . . . . . . . . . 27 


\section{PREFACE}

This report was written for several audiences. Therefore, compromises in presentation had to be made. In particular, it is designed to be used by Chinese officials and experts who are not familiar with the concepts underlying integrated resource planning (IRP) and, therefore, some sections may strike the reader sophisticated in such matters as overly detailed. On the other hand, the descriptions of the Chinese situation which are necessary to appreciate the application of IRP in this context may be seen as superficial by those knowledgable about Hainan and its energy sector.

The study was conducted under the auspices of the International Advisory Council on the Economic Development of Hainan in Harmony with the Natural Environment (IAC). It is based on visits to many energy-producing and energy-consuming sites throughout Hainan from April 4-April 11, 1992 and intensive multi-day meetings with Hainan officials and experts. We thank the Rockefeller Foundation for its financial support to the University of Tennessee's Energy, Environment, and Resource Center under Contract No. RF 92015, \#1. We also thank the U.S. Department of Energy for funding a portion of the study. By design, the visit to Hainan brought us in contact with many people, too numerous to acknowledge individually. However, we must acknowledge the assistance Professor Huang Zongdao, director of the IAC office in Haikou and his staff. He hosted the meetings in Haikou and coordinated the activities of team members and site visits. 


\section{INTRODUCTION AND EXECUTTVE SUMMARY}

This study identifies a strategy that (1) provides future energy services for Hainan in the least environmentally degrading way, (2) eliminates the need to build significant amounts of new fossil-fueled, electric generating capacity, saving capital to invest in other development projects, (3) lowers the cost that Hainan households and businesses will pay to light their homes and run their industries, (4) reduces the future coal import bill, and (5) improves the prospects for export industries. Implementing this strategy will promote economic development and growth in Hainan, improve the standard of living, and preserve to the greatest extent possible Hainan's rich environmental resource base, a key requirement for its tourist industry.

The focus of this strategy is to adapt proven policies and techniques for producing and using energy more efficiently to existing conditions in Hainan. This Report uses information on the Hainan situation as a starting point, and then applies the principles of integrated resource planning (IRP) and the experiences in other countries to outline a strategy for the Province. The experience is that fuel consumption can be reduced without lessening the ability of consumers, industry, and the government to obtain the energy services that higher use of fuel would otherwise bring. Further, those energy services can be provided with less capital investment than would be necessary if traditional practices were followed. Both of these results have obvious and important development and environmental benefits. In short, consumers have more money available to buy other things; production costs are lowered, improving the ability of firms to compete in international markets; and more capital is available to invest in new machinery and equipment that produces goods and services to use in Hainan or to export to other countries.

This is a preliminary report and much work needs to be done before a program can be designed and put into place. However, based on the preliminary survey, the conditions in Hainan are very favorable for the success of an IRP approach.

Moreover, this appears to be the appropriate time to move forward. Enough experience exists to conduct this program with a good expectation of success, yet it is early enough in utilization around the world that Hainan may obtain a competitive advantage by being ahead of its neighbors if it moves quickly. Further, the longer the delay in implementing this strategy, the greater the loss in potential benefits, especially in a fast-growing economy such as exists in Hainan. Major opportunities for energy savings are lost each year as factories are built and equipped, housing constructed, and appliances bought-all with inefficient energy use patterns.

If the Hainan government decides to adopt the strategy outlined here, the steps to be taken are reasonably well defined. A policy decision needs to be formulated and communicated; technical assistance needs to be acquired for the first stages of the analysis and to train Hainan officials and staff in the techniques involved; regulations and incentives need to be developed and implemented to foster changes in behavior and decisions; and a continuing Office designated and staffed to coordinate and sustain these activities over time. 
Use of the IRP approach is demonstrated in the body of the Report. IRP is a management tool that allows firms (for simplicity, we will concentrate here on electricity supply firms) to consistently compare the cost-effectiveness of all their resource options-those on both the demand and supply side--taking into account their different economic and reliability characteristics. Simply put, the IRP process increases the choices available to an electric firm in meeting its demand. The firm then selects the mix with the lowest cost, thereby increasing its chances of making more profit. Utilities in the West have found that they can cost-effectively lower capacity requirements by more than 25 percent using the IRP process. This occurs while simultaneously meeting all customer needs, and at lower costs per $\mathrm{kWh}$.

Using IRP principles, we identified potentially attractive, environmentally benign, politically feasible energy resource options for Hainan, including:

- using electricity pricing as a demand-side management (DSM) strategy;

- developing conservation building standards for new construction;

- implementing technical DSM programs in the household, commerce, industry, and transportation sectors of Hainan such as measures to increase the penetration of solar water heaters and more efficient lighiting and cooling systems;

- exploring the possibility of using wind on a larger scale to generate electricity.

The options are potentially attractive because they were not identified on the basis of rigorous analysis, but rather estimated based on the experiences of the authors with energy planning in other economies. Attractive is defined in the economic sense to mean that the benefits of implementing an option exceed its costs, where benefits for electric power options are defined as avoiding the cost of constructing and operating a coal generating unit, Hainan's marginal generating source. Although emphasis is placed on the electric power sector because of its high expected rate of demand growth and its importance environmentally, a major conclusion of the study is that the Hainan authorities should also look at the feasibility of implementing automobile traffic management measures, especially in the growing cities of Haikou and Sanya, and the Yang Pu area as it develops in the future.

In Table S.1, we summarize the potential effects of selected DSM programs on Hainan's electric power system in the year 2000. (Other parts of an IRP approach were not examined rigorously.) Projected electricity demand for the year 2000 is based on the Hainan government's forecast in its $8^{\text {th }}$ FYP. The data indicate that estimated electricity savings from implementing DSM programs are substantial. Assuming a 0.6 load factor, the 1,139 GWh of energy savings from the DSM programs in the year 2000 translate into 217 MW of capacity savings, which represent nearly 80 percent of Hainan's 1992 peak electricity demand. Assuming an avoided coal-fired unit with a $\$ 1,000$ per kilowatt capacity cost, the $217 \mathrm{MW}$ of capacity savings translate into a $\$ 217$ million monetary savings. Assuming $\$ 2,000$ per kilowatt, the savings increase to $\$ 434$ million or more than one-fifth of Hainan's 1992 gross domestic product.

The data in Table S.1 understate the benefits of implementing these programs. 
Table S.1

Summary of Potential Savings

Selected Demand-Side Management Measures

Hainan, China

2000

\begin{tabular}{|c|c|c|c|}
\hline \multirow{2}{*}{ Sector } & \multirow{2}{*}{$\begin{array}{l}\text { Forecasted } \\
\text { Demand (GWh) } \\
\text { in } 2000^{\circ}\end{array}$} & \multicolumn{2}{|c|}{ Energy Savings ${ }^{b}$} \\
\hline & & $\%$ & GWh \\
\hline $\begin{array}{l}\text { Households } \\
\text { Commerce } \\
\text { Industry }\end{array}$ & $\begin{array}{r}414 \\
650 \\
4,368 \\
\end{array}$ & $\begin{array}{l}25 \\
25 \\
20 \\
\end{array}$ & $\begin{array}{l}103 \\
162 \\
873 \\
\end{array}$ \\
\hline Total Energy (GWh) & 5,432 & 21 & 1,139 \\
\hline $\begin{array}{l}\text { Total Capacity Savings (MW) } \\
\text { Total Monetary Savings ( } \$ \text { Million), assuming-- } \\
\$ 1,000 \text { per kilowatt } \\
\$ 2,000 \text { per kilowatt }\end{array}$ & & & $\begin{array}{l}\$ 217 \\
\$ 434\end{array}$ \\
\hline
\end{tabular}

SOURCE: Analysis in text.

'Based on Hainan's Elghth Five-Year Plan.

'includes only the energy sevings. Does not include social and economic benefits; e.g., environmental beneits, macroeconomic benefits, export promotion, etc.

'Assuming a 0.6 load factor.

The cost per kilowatt of constructing a 200-MW coal plant in Hainan.

First, because of data and time constraints, we were not able to consider the full range of DSM possibilities and their interaction. For example, we did not quantify the effects of using cost-based electricity pricing as a DSM strategy. Second, we did not quantity the macroeconomic benefits of implementing DSM programs. In fact, one of the study's two recommendations is that Hainan authorities explore the possibility of developing a Center for Export Technologies which would be a test bed for developing energy efficient technologies and adapting them for use in mainland China and other Southeast Asian countries. That Center could eventually lead to development of a significant export industry. Another important macroeconomic benefit arises from the lower electricity costs resulting from implementation of the program. Besides the obvious benefits to customers in Hainan, lower electricity costs have the added benefit of making investments in 
Hainan's industries more attractive to foreign investors. Finally, the environmental benefits of not burning coal were not quantified.

And, those environmental benefits could be substantial. Besides the obvious direct benefits to citizens from reducing pollution discharge, improved environmental quality--together with traffic management in Haikou, Yang Pu, and Sanya--could be a boon for the tourist industry that the Hainan authorities are trying to stimulate. Also, although Hainan is not a major contributor to the greenhouse gas problem because of its small size, it could be a positive force for reducing greenhouse gas emissions by demonstrating to mainland China the process of evaluating resources and using technologies to control energy demand. As discussed above, the mechanism for accomplishing this technology transfer could be a Center for Export Technologies. This process could also serve as an investment magnet and export growth center, improving the productive capacity and industrial development of Hainan. Technologies and practices proven in Hainan could be exported to other Asian countries, perhaps leading to further economies of scale in manufacturing.

The other major recommendation of the study is that these DSM interventions be analyzed in depth using the principles of integrated energy planning within the context of Hainan's current electric power delivery system, its expected growth in demand, and conventional generating options. This initiative would require a commitment to (i) training, (ii) information-gathering on Hainan's electricity customers and their consuming habits, and (iii) comparing the characteristics of demand and supply resources. These activities could be jointly conducted with other research organizations in China.

We make these recommendations recognizing that Hainan currently has excess generating capacity. However, despite this excess, this is an ideal time in Hainan's development to implement integrated energy planning. For one thing, Hainan's economic output is expected to double in a five-year period with a corresponding increase in electricity consumption. That consumption increased by nearly 40 percent in 1991 and is expected to grow at nearly the same rate this year. Before long. Hainan's excess capacity will deteriorate into a deficiency.

Second, many of the demand-side management (DSM) programs identified in this study have long lead times before reaching maximum penetration into the market. Related to this, it will take a considerable amount of time to (i) assemble the necessary data to develop DSM programs tailored to Hainan's conditions, (ii) compare them with the costs of building new power plants, and (iii) implement the cost-effective programs.

Third, Hainan's current low level of income implies modest penetration of the most electricity-intensive durables. Economic development implies higher income levels and the penetration of new and different types of electricity-using durables such as water heaters, air conditioners, refrigerators, and lighting. The abilit; of the government to promote the use of energy-efficient durable goods is much greater before those types of products have had much time to penetrate Hainan's markets. There is inertia in an existing stock of electricity-using durable goods, implying that they will not be readily traded for more efficient new ones in the short term even if better means of meeting needs exist. The longer the delay, the greater the sacrifice in Hainan's future well-being. 
Finally, regional and global environmental concerns about generating electricity from coal focus special attention on Hainan's power sector. Because Hainan's hydroelectric resource base is nearly exhausted, its avoided power source is coal. Therefore, any reduction in electricity demand in Hainan will serve to reduce emissions from coal-burning power plants. 


\section{BACKGROUND}

\subsection{THE ENERGY STUATION IN CHINA}

China is struggling, along with the rest of the world, to provide energy services to support economic growth and a rising standard of living while improving environmental quality. The situation is especially difficult for China because these tasks must be performed in the face of a rapidly expanding population, burgeoning effective demand per-capita from the consumer sector, an urbanization movement which places more demands on using modern fuels, growing industrialization, and a pervasive shortage of capital. In general, environmental resources are already stressed; success demands that these added energy services be provided while simultaneously reducing existing emissions which are already beyond those which can be tolerated in the long term (Perlack, Russell, and Shen, 1991).

Under these circumstances, the approach of integrated Resource Planning (IRP), which has been pioneered elsewhere in the world, appears especially attractive. This Report describes the IRP approach, discusses the results obtained elsewhere, and suggests how IRP might be applied to Hainan Province as a test bed for evaluating its promise for other areas in China. The primary focus in this Report is on the provision of electricity services because that is where the opportunities appear greatest and the experience is most complete. The same principles, however, can be extended to provision of other energy services.

\subsection{WHAT IS INTEGRATED RESOURCE PLANNING?}

Spurred by the rising costs of constructing new electric generating plants, high fuel costs, and increasing environmental concerns over emissions from fossil fuel plants, electricity producers in many countries are looking to the demand side as a source of resources for meeting energy (i.e., kWh) and load (i.e., kW) requirements. That is, changing the pattern and level of electricity (i.e., demand-side management (DSM)) is weighed as a resource option on an equal footing with trad "Jonal supply resources (e.g., building new generating stations, extending the iffe of old ones). The process of selecting a resource mix on the basis of comparing the benefits and costs of demand and supply resources is referred to as integrated resource planning (IRP). The IRP process is a combination of (1) traditional least-cost planning, a process by which utilities minimized the cost of generating a given amount of electricity and (2) demand-side planning. Its goal is to provide needed electricity at the lowest possible economic, social, and environmental cost.

In Figure 1, we place DSM planning in the context of a dynamic electric utility planning framework, including (1) factors that motivate utilities to consider DSM planning, (2) the relationship between demand-side planning and the IRP process, and (3) DSM program implementation and evaluation (Hill, Hirst, and Schweitzer, 1991). The process is dynamic not only because planning by its very nature is evolutionary but also, as we show in Figure 1, because the effectiveness of DSM programs has feedback effects on both the process of selecting the programs and the way in which they are implemented. 
Figure 1

Integrated Resource Planning as Part of a Dynamic Process

\begin{tabular}{|l|}
\hline Utillty Motivation \\
\hline Supphy Characterietics \\
Demand Characterietica \\
\end{tabular}

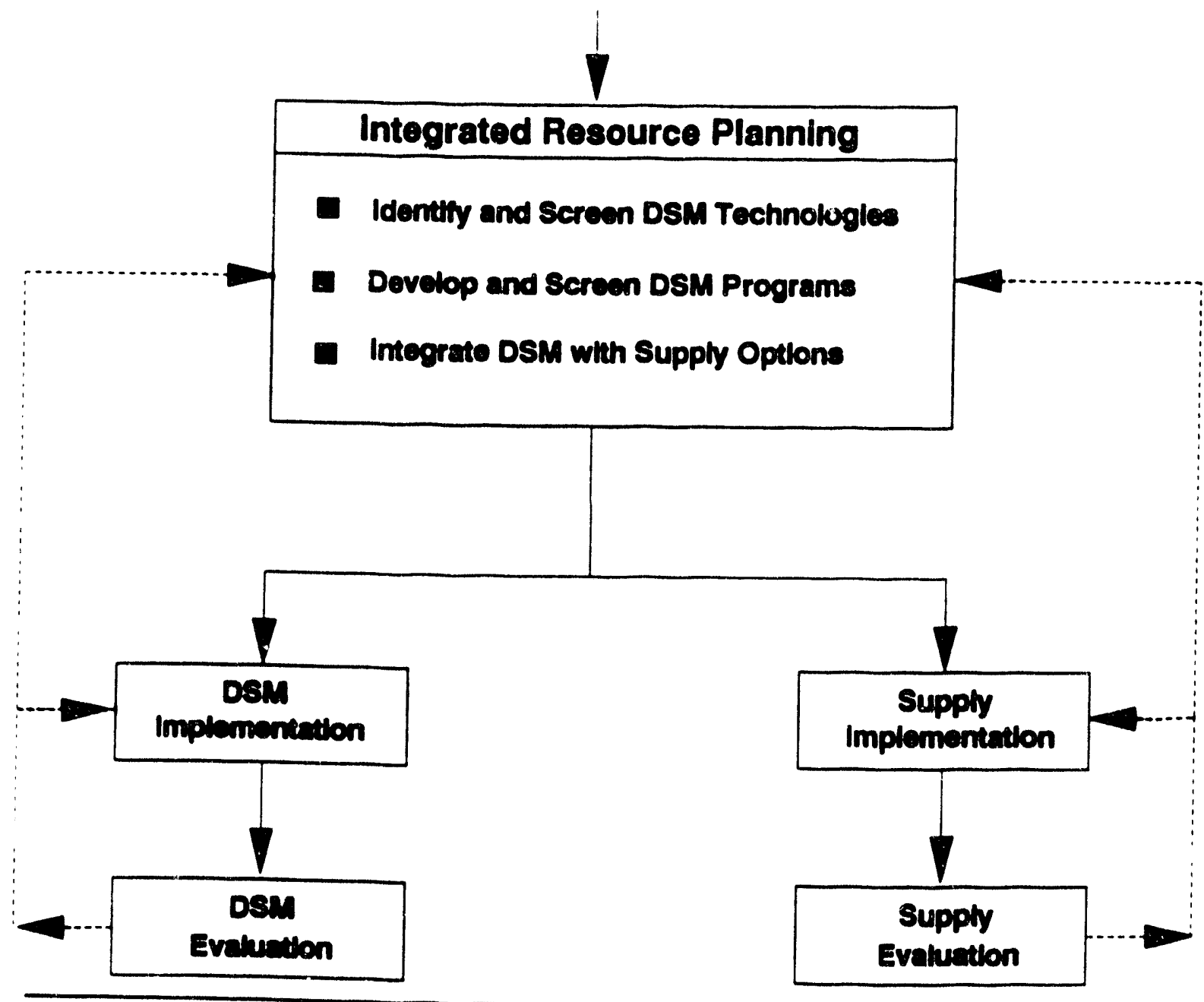


The effectiveness of DSM programs, of course, can be determined only by systematic program evaluation (Hill, Hirst, and Schweitzer, 1992a).

As we show in Figure 1, characteristics of both the power delivery system and customer demand influence decisionmaking on whether to engage in DSM planning. For example, the types of generating units used by electric utilities can be a motivating force to engage in DSM planning. Based on statistical analysis of 24 U.S. utilities, the percent of total peak ( $\mathrm{kW}$ ) rescurces projected to be met by DSM is larger for utilities with greater dependence on oil and gas generating units for peaking purposes, which have higher costs per kWh generate... Similar conclusions result from energy consumption (kWh) avoided by conservation programs. That is, if production costs are higher, firms try harder to promote reductions in use by their consumers (Schweitzer, Hirst, and Hill, 1991). On the demand side, utilities with low load factors are more likely to seek ways to shave peak load. There are several powertul DSM tools that can be used to accomplish this, including electricity pricing (Hill, 1990, 1991a). The goal in all cases is to find the mix of supply and demand resources that lowers present and future costs and, therefore, increases potential profits and the amount of capital available for reinvestment.

The integrated planning process shown in the middle box of Table 1 will be discussed in depth in Section 3. Therefore, we defer discussion of the process until then.

The final two sets of blocks on implementation and evaluation are important. DSM programs are implemented and evaluated in the same way that supply resources are. That is, DSM programs are treated parallel to the manner in which a utility chooses to (1) build a power plant, (2) construct it, and (3) evaluate its performance. As we discuss in Section 3, the problem that many utilities confront in treating DSM and supply resources in a parallel manner is the lack of data on running DSM programs. The technical savings of these programs are generally well known. It is the marketing side where utilities are deficient because firms do not have enough information to know how their decisions will affect their potential profits. They need information on:

- the number of customers using different types of electricity-using durables and, therefore, the total amount of savings available from a program;

- the possible market penetration of energy-efficient durables;

- quantification of the trade-offs between marketing these durables and their penetration,

- the most effective financing mechanisms for different programs.

\subsection{HOW MUCH SAVNGS ARE POSSIBLE?}

In Table 1, we present some evidence on the contribution of DSM programs to meeting future electric energy (kWh) and peak load (kW) in the United States. The results are based on survey responses from 24 U.S. electric utilities (Schweitzer, Hirst, and Hill, 1991). The 24 utilities represent one-third of the U.S. electric utility industry in terms of peak load. The survey results are presented on two bases in Table 1: (1) the percentage of total resources (i.e., energy services supplied) accounted for by running DSM programs, which is the percentage reduction of total demand attributable to running DSM programs and (2) the percentage of incremental resources (i.e., energy services supplied) 
accounted for by running DSM programs, which is the fraction of additional resources added by utilities in the 10-year period from 1990 to 2000 that are accounted for by DSM programs.

\begin{tabular}{|c|c|c|c|c|}
\hline \multicolumn{5}{|c|}{$\begin{array}{l}\text { Table } 1 \\
\text { Estimated Energy and Peak Load Savings from DSM Programs } \\
\text { U.S. Electric Utilities } \\
1990 \text { and } 2000 \\
\text { (In Percentages) }\end{array}$} \\
\hline \multirow{2}{*}{ Type of Savings } & \multicolumn{2}{|c|}{ Energy } & \multicolumn{2}{|c|}{ Peak Load } \\
\hline & 1990 & 2000 & 1990 & 2000 \\
\hline Total Resource Basis & 0.5 & 3.8 & 1.3 & 6.2 \\
\hline Incremental Resource Basis & NA & 15.5 & NA & 27.7 \\
\hline
\end{tabular}

SOURCE: Schweitzer, Hirst, and Hill, 1991.

Weighted average, basid on responses from 24 unilities. Peak could occur in the summer or winter depending on the demand charecteristics of inolvidual utillies.

NA - Nor Applicable

To facilitate understanding these two bases, we characterize them in Figure 2 (Hill, Hirst, and Schweitzer, 1991). The No Incremental DSM curve is a reference forecast from the Current Year forward, a best-guess of what load is going to be before including the estimated effects of DSM options. The Projected Load curve is a forecast of future load requirements, including the effects of DSM programs. Existing Supply Resources refers to the amount of generating capacity that is committed and known at the time the plan is being developed. That amount is shown dectining over the forecast horizon in Figure 2 , implying a net depreciation of supply resources.

The survey results shown in Table 1 indicate that U.S. utilities will significantly increase their DSM activities on a total resource basis from 1990 to 2000 . In the year 2000 , peak demand, for example, is forecasted by these 24 utilities to be 6.2 percent less than it otherwise would be if DSM programs were not implemented. The savings on an incremental basis are much larger, of course. Nearly 30 percent of auditional peak electric power resources (kW) will come from the demand side in 2000 . Projected energy savings (KWh) are one-half of projected peak lood savings, suggesting that load management programs (e.g., direct load coritrol programs that change the time when 
electricity is used) are more pervasive and/or effective than those aimed at improving energy efficiency (e.g., conservation programs).

Figure 2

Incremental and Total DSM and Supply Resources

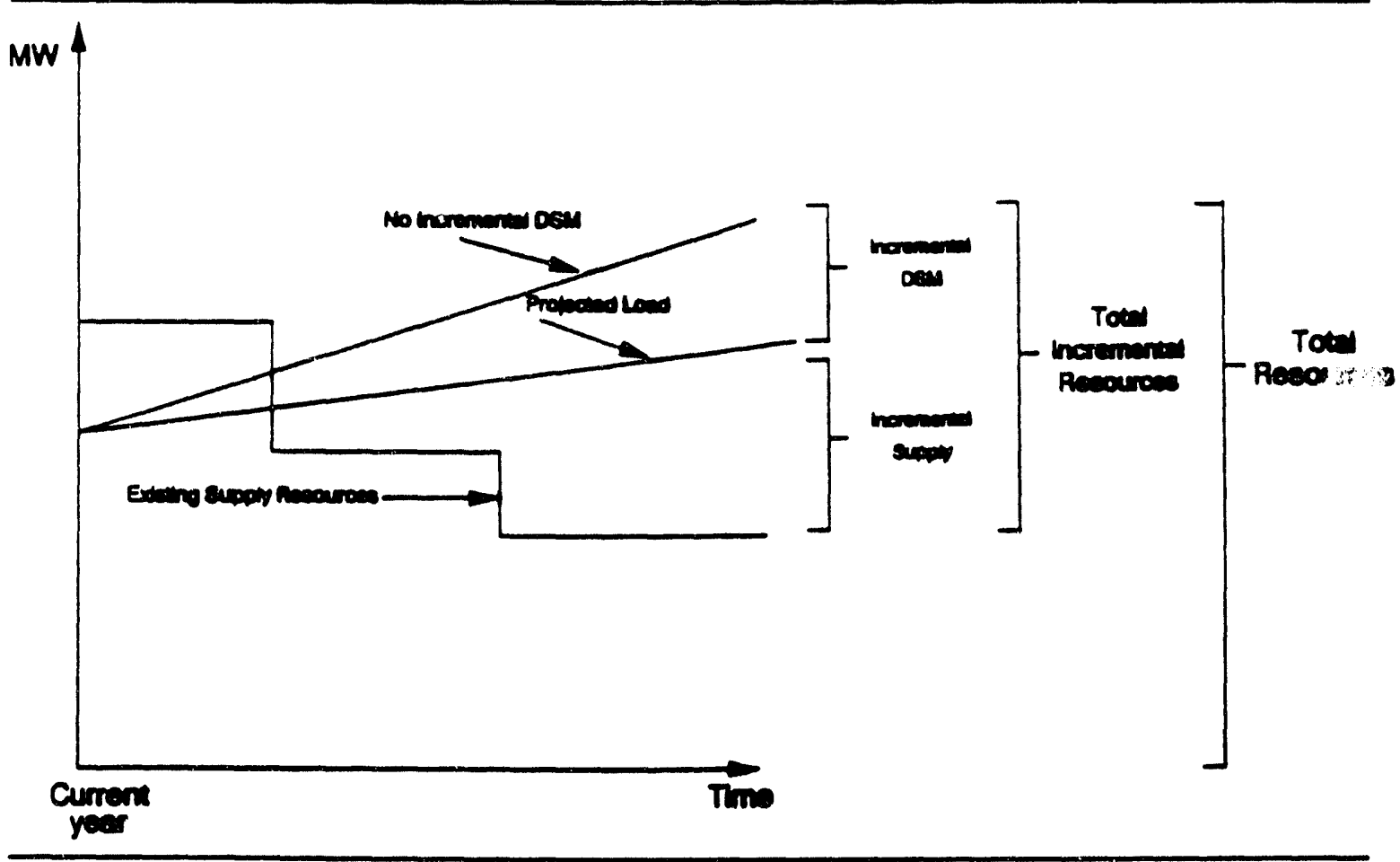

The data in Table 1 are weighted averages of the 24 utilities responding to the survey. Clearly, different utilities with different operating conditions will have different potentials for DSM savings. For example, all other conditions the same, utilities that aggressively pursued DSM programs in the past will not have the same savings potential ten years from now as those utilities just beginning DSM planning. Utilities with different climates and different load factors will also have different DSM potentials. To demonstrate different potentials across utilities, in Figure 3 we disaggregate the survey results presented in Table 1 to an individual uility level for the incremental resource projections. Some of the utilities are projected to get as much as one-half of their additional energy and peak load resources in the the next ten years from DSM resources. Other utilities, on the other hand, will not be getting as much as five percent of their energy requirements from DSM programs.

\subsection{SCOPE AND ORGANIZATION OF THE STUDY}

In Figure 1, we showed how the IRP process fits into a larger, dynamic setting. In Section 3.1, we expand on this discussion, providing a step-by-step procedure for the 
process: data requirements, development of DSM programs, selection and use of models, and the like. Data and time limitations prevent us from conducting a full-scale IRP study here. Nonetheless, in Section 3.2 we indicate possible savings from implementing DSM programs in Hainan in the year 2000. We select programs that are the most attractive-i.e., the r:-hest expected benefit:cost ratios--from experiences with these programs in other parts of the world that are similar in size, climate, and stage of development to Hainan. Jamaica and the U.S. Virgin Islands were singled out for these reasons.

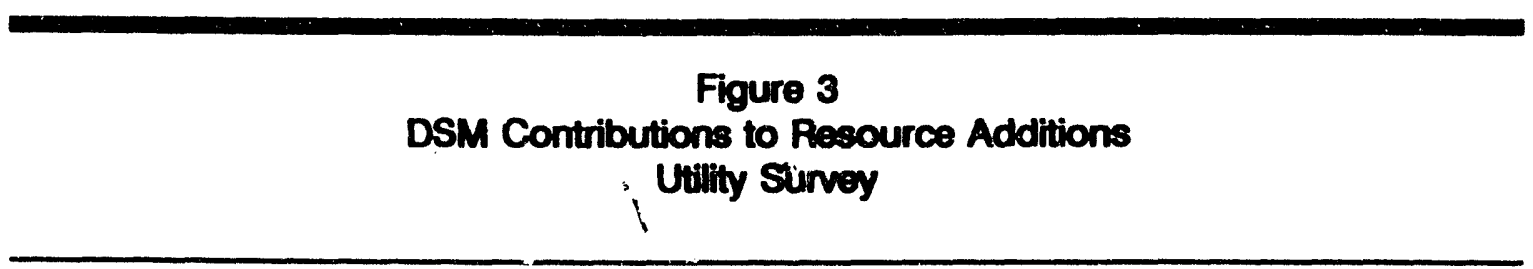

\% OF 1990-2000 ADDITIONS FROM DSM

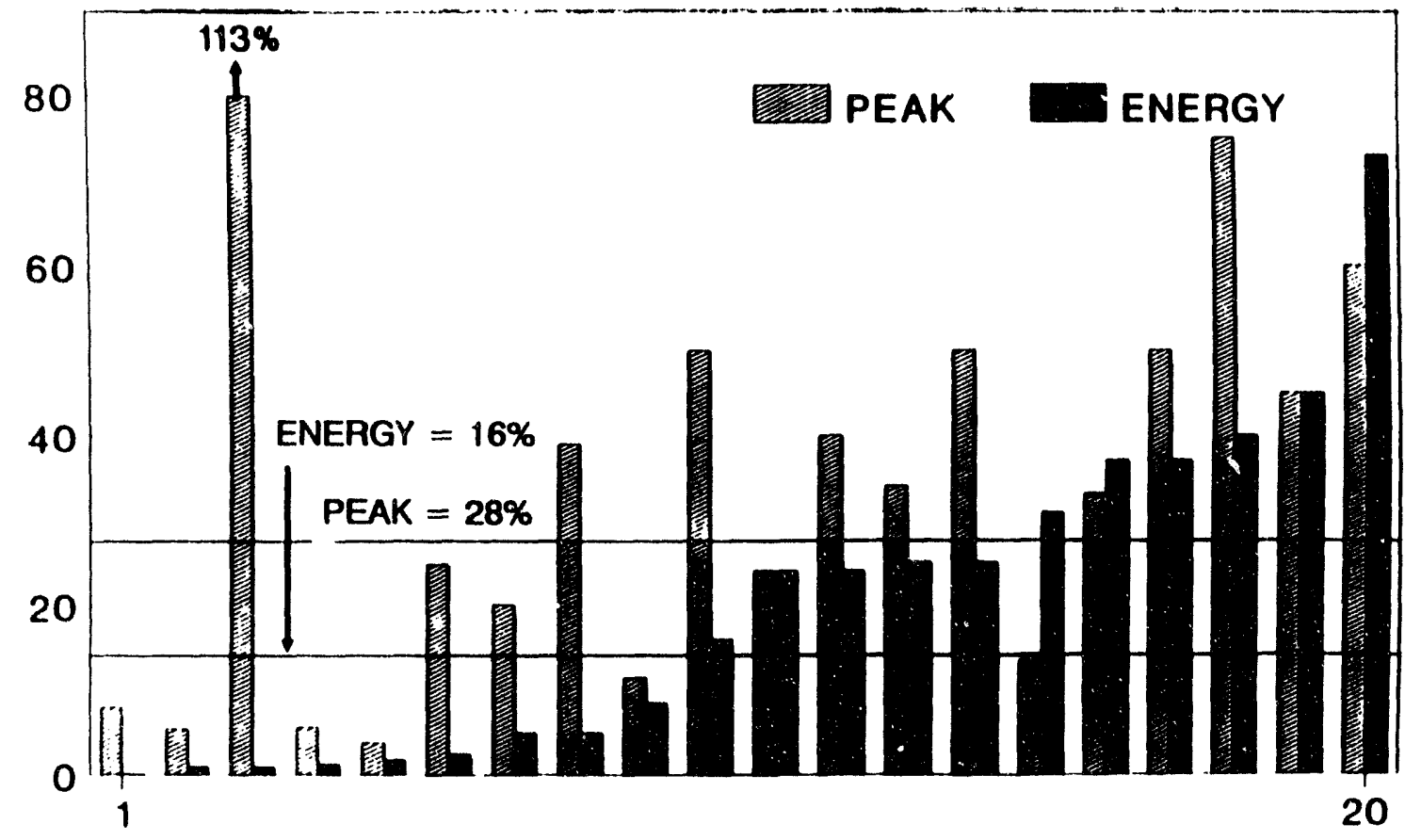

ELECTRIC FIRMS

In Sections 4 through 6, we discuss the alternatives to constructing fossil-fuel generating plants in greater detail. In Section 4, technical DSM possibilities are addressed. We organize the discussion around two topics: (1) conservation building standards and (2) DSM possibilities by sector--households, commerce, and industry for electricity and traffic management for the cities of Haikou and Sanya and the Yang Pu region. Electricity pricing as a DSM strategy is discussed in Section 5. Here, we look at the industrialized countries' experience with such pricing strategies as time-of-day pricing and interruptible tariffs. We then apply these experiences to Hainan. Here again, data 
limitations prevent quantifying the effects of implementing these strategies in Hainan; they are discussed qualitatively. In Section 6, we discuss possible cost-effective renewable energy applications. On the supply side, we look at the possibility of using more windbased electricity generation. On the demand side, we discuss solar water heating.

We conclude in Section 7 with two recommendations for the Hainan government. The first urges that the government begin immediately to establish a mechanism for instituting an IRP process. In the second, we suggest that the government take advantage of its experience with IRP by promoting an export industry for the conservation technologies identified as part of the IRP process.

Before beginning, it will be helpful to provide an overview of Hainan and its economy for the reader unfamiliar with China's largest special economic zone. We do this in the next section. We emphasize Hainan's energy sector in the discussion. 


\section{OVERMEW OF HAINAN}

\subsection{BACKGROUND ON HANAN'S ECONOMY}

From 1979 to 1982, the Chinese government created four special economic zones (SEZs) on the Southeastern coast of China: Xiamen, Shantou, Shenzen, and Zhuhai. An SEZ is an area designated to carry out the export-development portion of China's mixed development strategy. That strategy includes both import substitution and export-oriented development: inland areas are consigned to import substitution activities, while the SEZs are engaged in export-related activity.

In 1988, Hainan Island off the Southeast coast of China was separated from Guangdong Province, organized as a separate Province, and designated China's fifth-and largest--SEZ. Hainan has a long history of commercial and industrial contacts outside of China. Also, much of the overseas Chinese population comes from southeastern China, providing linkages with this region to the rest of the world.

SEZs are not intended to be isolated from the mainland Chinese economy. Rather, they are intended to be "bridges" between the mainland and the international economy. The central government in Beijing establishes the general guidelines for economic activity in the SEZs. From this basic blueprint, local authorities are free to make economic decisions to suit the conditions of their area and of international trade. The regulatory environment for those decisions, of course, is different from that governing other areas of China.

H'ainan's economic development strategy is export-oriented, loosely modeled after those of South Korea, Taiwan, and Hong Kong. The success of that strategy and economic development depend on Hainan's ability to harness domestic savings and attract foreign investment. Thus far, a stock market has been created in Haikou with four firms licensed to use it. A foreign exchange market exists where currencies are freely traded and their prices determined by market conditions. A bond market is in the process of being organized. The government has made a special effort to attract foreign investment, especially in Yang Pu, a port region on the Western coast of Hainan, where it created a 30-square kilometer "special" special economic zone. For the first time in China, enterprises in that zone will be permitted to issue bonds and equity shares using fixed assets as security to raise funds from foreign investors.

Thus far the economic reforms have been fairly succosstul. From 1990-1995, government planners project the economy to grow at the rate of 16 percent per year, and to increase six-fold by the year 2000 (Table 2). GDP per-capita will nearly triple over the same time period, from $\$ 268$ in 1990 to $\$ 734$ in 2000 .

A limiting factor in Hainan's growth ironically may be a lack of labor. Table 2 shows that government planners expect the population to increase by 1.6 million people over the decade, from 6.6 to 8.2 million people. This population level may not be consistent with attracting labor-intensive industries as part of its development strategy. 


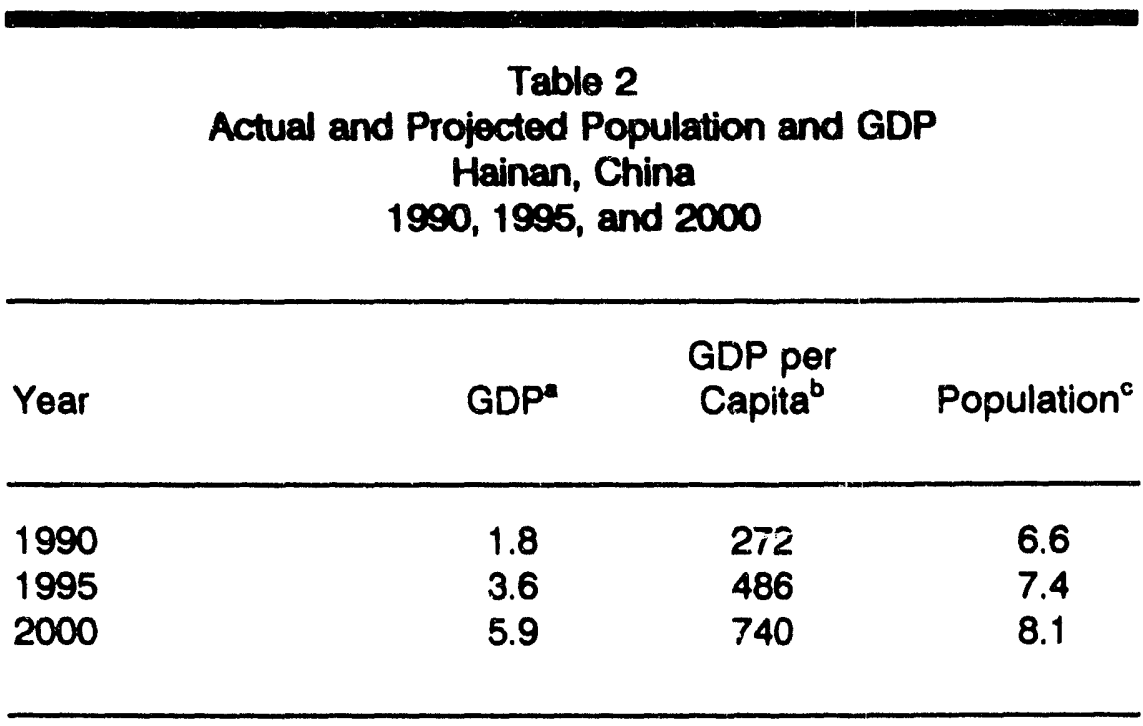

SOURCE: Hainan Electricity Bureau.

"In billions of U.S. dollars; based on an exchange rate of 5.3 Yuan per U.S. dollar.

in U.S. dollars; based on an exchange rate of 5.3 Yuan per U.S. dollar.

In millions.

\subsection{AN OVERMEW OF THE ENERGY SECTOR}

\subsubsection{Energy Balance}

Historically, Hainan has imported most of its energy requirements--primarily from the mainland. Its major imports include coal, diesel, gasoline and charcoal. It has no known reserves of crude oil. Hainan's major energy resources include oil shale, a lowgrade brown lignite, and some off-shore natural gas approaching 168 billion $\mathrm{m}^{3}$. Most of the annual production of that gas, however, is destined for Hong Kong on the basis of an agreement signed by the parties in March 1992.

The isiand also has some potentially cost-effective renewable energy forms, including the sun, wind, and biomass. The exact amounts of these resources awaits indepth studies.

\subsubsection{A Closer Look at the Power Sector}

In Table 3, we show the electric generating capacity of the Hainan provincial grid. As footnote a notes, total grid capacity of $626 \mathrm{MW}$ understates the total amount on the island by $160 \mathrm{MW}$ which is owned by self-generators such as sugar mills, small, isolated hydropower stations, and the like. Generating capacity is expected to increase to 866 MW by 1995, with completion of a $240-\mathrm{MW}$ hydropower station at Da Guang Ba. Capacity is then expected to increase to 1,590 by 2000 , reflecting in large measure 600 
MW of new coal-fired capacity at Basao. This $600 \mathrm{MW}$ was initially designed to be gasfired, with the natural gas coming from the off-shore gas discoveries. However, most of the natural gas is now scheduled to be exported to Hong Kong on the basis of a recently signed deal (March 1992) between a Chinese-American joint venture and the Hong Kong utility. If more gas is discovered--and there are indications that it may be--the $600 \mathrm{MW}$ at Basao could be converted to natural gas.

Table 3

Actual and Projected Growth of Generating Capacity Hainan, China Provincial Grid 1992, 1995, and 2000 (in Megawatts)

\begin{tabular}{lrrr}
\hline Year & Coal & Hydro & Total \\
\hline $1992^{\circ}$ & 439 & 187 & 626 \\
1995 & 439 & 427 & 866 \\
$2000^{\circ}$ & 1,039 & 551 & 1,590 \\
\hline
\end{tabular}

SOURCE: Hainan Electricity Burbau.

Capacity of the provincial grid only; does not include $160 \mathrm{MW}$ of off-grid capacity.

'Does not include 1,300 MW of planned capactly in Yang Pu which will be built by private interests.

As Footnote $b$ in Table 3 indicates, total generating capacity in the year 2000 would be almost doubled if the 1,300 MW, coal-fired units at Yang Pu were included in the total. This capacity is to be built in three phases $(2 \times 100 \mathrm{MW}, 2 \times 200 \mathrm{MW}$, and $2 \times 350$ $\mathrm{MW}$ ). Present plans are that these facilities will be constructed and operated by private interests (probably Japanese) as part of the development strategy of the "special" SEZ in Yang Pu and semi-isolated from the provincial grid. This decision is still in flux because management of the Electricity Bureau seeks to integrate those facilities into its own construction and operating program.

This marked growth in electric generating capacity, of course, mirrors the projected growth in electricity demand. In Table 4, we show that electricity demand is expected to grow by five-fold over the $1990-2000$ period, reflecting in large part the growth in industrial use of electricity from 6 tWh in 1990 to 44 tWh in 2000. 


\begin{tabular}{|c|c|c|c|}
\hline \multicolumn{4}{|c|}{$\begin{array}{l}\text { Table } 4 \\
\text { Actual and Projected Growth in Electricity Consumption } \\
\text { Hainan, China } \\
\text { 1990, 1995, and } 2000 \\
\text { (In GWh) }\end{array}$} \\
\hline Sector & 1990 & 1995 & 2000 \\
\hline $\begin{array}{l}\text { Households } \\
\text { Commerce } \\
\text { Industry } \\
\text { Agriculture }\end{array}$ & $\begin{array}{r}233 \\
239 \\
595 \\
68\end{array}$ & $\begin{array}{r}380 \\
325 \\
2,003 \\
92\end{array}$ & $\begin{array}{r}414 \\
650 \\
4,368 \\
108\end{array}$ \\
\hline Total & 1,135 & 2,800 & 5,540 \\
\hline
\end{tabular}

SOURCE: Hainan Electricity Bureau.

\subsubsection{Energy Pricing}

Currently, electricity prices are set to recover (i) variable costs of producing electricity, (ii) a tax to support operation of the Electricity Bureau, and (iii) a return for capital employed in producing electricity. Evidence is that revenues at present fall short of meeting these goals and electricity is subsidized. To increase prices, the Electricity Bureau submits relevant financial information to the Provincial Price Bureau which determines whether prices should be increased, taking social, economic, and provincial goals into account. Provincial prices for key commodities such as electricity are based on national prices determined in Beijing, adjusted for local conditions. Other key commodities subject to price controls are steel, cement, and timber. Gasoline prices are subject to price controls, but in a little bit different way. They are based on a two-tiered pricing system in which the first tier is coupon-based and the second tier is based on market forces.

\subsubsection{Energy Conservation}

Currently, responsibilities for energy conservation activities are lodged in a number of different institutions. For example, industrial electricity conservation rests in the Office of Conservation of the Bureau of Industry. The Office can tell industry to stop consuming electricity if it exceeds a certain level, but no sophisticated energy conservation analysis or operational program exists. The responsibility for petroleum and gas conservation rests with their respective national companies. 
In the future, an Energy Conservation Bureau will be created to consolidate most of the energy conservation activities. That Bureau will administer a proposed Energy Conservation Fund which will be used to heip finance energy conservation investments. Funding for the bureau will come from the central government in Beijing, the Provincial government in Haikou, and foreign borrowing. Unfortunately, this energy conservation funding source will be made available primarily to large, state-owned, energy users. Smaller energy users must still rely on the older system of financing energy conservation improvements from local financing sources. 


\section{AN INDICATION OF POSSIBLE SAVINGS FROM IRP}

\subsection{PROCEDURES FOR DETERMINING COST-EFFECTIVE OPTIONS}

In practice, electric utilities that practice IRP use different approaches, varying from the simple to the complex. One reason for differences in the United States is regulatory requirements in the different jurisdictions in which the utilities are found. Another reason for differences is experience. Because IRP is a recent phenomenon, many utilities are just beginning to wrestle with the more complex aspects of IRP, such as the type of integrating method to use. Utilities that have engaged in IRP over a period of time are likely to have developed an organizational structure and in-house expertise to use more sophisticated approaches (Hill, Hirst, and Schweitzer, 1992C).

An important difference in the approaches used by utilities is the way in which DSM options are characterized. Some utilities compare DSM technologies with supply resources. To illustrate, a fluorescent lighting technology for commercial customers is compared with a new generating unit. Other utilities aggregate DSM technologies to varying degrees and compare the aggregate with supply resources. Aggregating three different commercial lighting technologies on the basis of market segments is an example. It is more appropriate to these programs. A DSM program is a group of technologies combined for marketing to a specific customer group. Ideally, technologies are combined in a package to complement rather than compete against one another (Hill, Hirst, and Schweitzer, 1992a).

We showed how development of these DSM programs from technologies fits into a three-phase integrated planning framework in Figure 1:

- Identifying and screening DSM technologies,

- Developing and screening DSM programs, and

- Integrating those programs with candidate resources on the supply side to develop a coherent resource plan.

Developing DSM programs requires that technologies first be identified and then evaluated for appropriateness to a utility's customers. A mechanism must then be developed to transform the technologies into DSM programs.

A major problem is the enormous amount of data required to accomplish this. Those requirements relate to (1) information on prospective participation in DSM programs, (2) quantifying the savings resulting from implementation of the programs, and (3) the costs incurred by the utility and customer to participate in a program. To determine the number of potential participants in a DSM program, a significant amount of information must be known about the targeted group's prospective electricity consuming behavior (e.g., amount and type of end uses, time of day). This is particularly difficult to obtain in a fast-changing situation such as will exist in Hainan. In determining savings from a technology, a distinction must be made between total savings (i.e., the reduction in electricity use by participating customers) and net savings (the portion of total savings that can be attributed to the DSM program). Therefore, a significant effort must be expended on analyzing savings due to secular trends, endogenous and 
exogenous factors such as income effects and price effects. In a developing country context, those can be substantial. For example, net fuel savings from efficient stove programs have been found to be far less than projected because utilization increases.

A number of models have been developed to assess DSM and supply resources with varying degrees of analytical complexity and data requirements. Examples include the Multiobjective Integrated Decision Analysis System (MIDAS) developed for the Electric Power Research Institute (Temple, Barker, and Sloane, 1988), UPlan developed by the Lotus Consulting Group (1988), the Decision Impact Assessment Model (DIAMOND) developed by Oak Ridge National Laboratory (Gettings, Hirst, and Yourstone, 1991), and Scenario Analysis Framework for Expansion Planning (SAFEPLAN) (Policy Planning Associates, 1990). The more important characteristics included in these models (with possibilities) are:

- capacity expansion capability (yes, no),

- treatment of time-of-use variations in demand (load duration curve, chronological),

- production costing routine (yes, no),

- financial simulation module (yes, no),

- treatment of uncertainty (yes, no).

The degree of complexity of a planning model--and user unfriendliness--is related to the manner in which each of these characteristics is treated. A model that has capabilities to:

\footnotetext{
- select an optimal mix of resources,

- characterize demand for 8,760-hour years for every year over the planning horizon,

- determine the variable costs of employing supply-side resources,

- simulate the financial performance of the utility, and

- include uncertainties in resource selection
}

tends to be very large and complex with significant data requirements. Obviously substantially less complex models can be usefully deployed and provide many if not most of the outputs and decision insights required at much lower cost. Complexity can be added as the situation justifies.

Once a model has been selected, an integrating method must be chosen. Three methods can be used to integrate DSM and supply resources: (1) a sequential approach in which DSM resources are selected first; (2) a sequential approach in which supply resources are selected first; and (3) a simultaneous approach in which resources are selected jointly using some measure of cost-effectiveness as a guide. Assuming that the objective of utilities is to minimize their costs, each of the three should theoretically result in selection of the same set of resources. In practice, however, they do not. If a utility's goal is to find the resource mix that minimizes its cost, it should use the simultaneous integrating method (Hill, 1992b).

It bears noting that the promise underlying each of these approaches is that 
social, economic, and environmental values are fully reflected in the conditions (prices) by which each prospective source is obtained. Sometimes, though, especially in a developing country context, externalities are not fully captured--differing employment effects, balance of payment constraints, equity concerns, etc.--and in that case explicit attention to these is required in the integrating process.

Because of their complexity, however, simultaneous integrating methods require considerably more expertise and commitment of staff and financial resources by an electric utility than the two sequential approaches. The costs of these additional planning requirements, however, must be weighed against the benefits of obtaining a resource portfolio that moves the utility closer to minimizing its total cost of service.

Different dimensions of ressources also complicate the integrating process and increase the cost of using variants of the simultaneous approaches in comparison with the sequential ones (Hill, Hirst, and Schweitzer, 1992b). That is, although DSM programs and supply resources have the common characteristic of meeting future energy and capacity requirtments, they may differ along three dimensions: (1) financial, (2) economic, including externality and value of service considerations, and (3) reliability.

The financial criterion for selecting resources significantly influences resource mix. In the United States, four tests originally developed for California utilities are widely used to determine the cost-effectiveness of DSM programs (California Public Utilities Commission and California Energy Commission). Assuming no externalities are included in the calcllations (discussed below), the tests measure financial impacts of these programs through consideration of:

- Participants' Test, which measures the net financial impact on customers participating in a DSM program, including any payments received from a utility and any out-of-pocket costs incurred by the customer;

- Ratepayer Impact Measure, which measures the impact of a resource option on electricity prices for all customers;

- Total Resource Cost Test, which measures the net change in costs of an option to both participants in the program and nonparticipants; and

- Utility Cost Test, which measures the net change in a utility's costs.

The tests have different objectives and, therefore, capture the financial aspects of DSM programs from different perspectives. The participants test, for example, measures net benefits exclusively from the standpoint of the customers participating in a DSM program and, therefore, provides a good indication of the receptivity of different customers to a program. The ratepayer impact measure is the only test that captures the change in revenues resulting from DSM programs and, therefore, is used widely to determine a program's effect on electricity rates. The last two tests, on the other hand, determine a program's effect on costs exclusively. The total resource cost test measures the effect on the sum of customers' and utility's costs, while the utility cost test (also called the revenue requirements test) measures the change in revenues required by a utility as a result of changes in its costs (Hill, Hirst, and Schweitzer, 1992b).

The societal test, a variant of the total resource cost test, extends the comparison 
of resources from a financial to an economic basis. That is, external costs and benefits are included in an economic comparison of resources--in addition to financial costs and benefits. A complicating factor is that these benefits and costs are diffic dit to quantify in many cases because they are not generally determined in markets. For sxample, a direct load control program or interruptible tariff may be cost-effective to bot. I customers and the utility in monetary terms, but the loss of amenity (i.e., convenience) in not being able to consume electricity at certain times of the day and/or year may significantly depreciate the monetary gains accruing to customers, a loss in value of service (VOS).

VOS refers to the price-consumption relationship in the market for electricity. It typically applies to DSM programs because they directly affect the price of electricity and consuming habits of electricity customers. However, carrying the argument further, employing any resource can have an effect on VOS if it changes the price of electricity. For example, a utility that purchases power during times of system peak rather than constructing new capacity can affect VOS if electricity prices are affected.

Macroeconomic effects can also provide substantial externalities. For example, the macroeconomic effects of using DSM programs in place of supply resources may have transitory regional and national employment effects. A ajcision not to construct a new power plant, for example, will result in a loss of jobs and income as a first order effect in some locations. On the other hand, a DSM program reducing imported petroleum requirements may affect the balance of payments.

The external environmental effects of using different resources are becoming more and more important in electric utility planning. From the supply side, operating power plants harmful to the environment may give DSM programs an economic advantage if the environmental costs of operating the plants could be quantified.

Estimating a resource's reliability is important in determining its cost-effectiveness. In determining benefit-cost ratios, for example, estimates of reliability are important in quantifying the benefits (i.e., avoided costs) of using resources. The challenge in utility planning is to characterize properly the reliability effects of DSM resources, allowing those resources to "compete" against one another over time for energy and load share, satisfying the input assumptions (e.g., load forecast, fuel prices, capital costs) and solution criteria of the models used to make the estimates (Hill, Hirst, and Schweitzer, 1991).

\subsection{APPUCATION USED IN THIS STUDY}

Unfortunately, because of time, data, and other resource constraints, this study could not get follow the procedures practiced by some of the more advanced utilities. Indeed, the situation in Hainan is radically different from that of the United States and it would be totally inappropriate to attempt to replicate any of the models outlined above in Hainan. Nonetheless, the principles which underlie existing applications are universal, and can be adapted to provide a distinctly Chinese application of IRP suitable to Hainan. A major recommendation of the study (presented in Section 7) is that the Hainan Electricity Bureau develop the capability to undertake an integrated planning effort suitable for conditions in Hainan. This has already been done in regions similar to Hainan 
and that experience demonstrates the robustness of this approach.

There is enough information available from the experiences of other utilities in other parts of the world to indicate the types of programs that are likely to prove costeffective in Hainan and to develop some very gross savings estimates. Rather than basing the estimates on the experiences of electric utilities in the United States or Europe, however, we take the experiences of Jamaica (Conservation Law Foundation, 1990) and the ongoing study in the U.S. Virgin Islands (Hill, Chronowski, and Shapiro, 1992). Jamaica has a similar climate to that of Hainan and is in the same stages of development. Its per-capita gross national product is $\$ 1,500$ in comparison with $\$ 400$ for Hainan. In 1990, the year that the study was conducted, the peak load for the Jamaica Public Service Company, the single electric utility in Jamaica, was $300 \mathrm{MW}$. This year, Hainan's peak load is $280 \mathrm{MW}$. Similarly, the U.S. Virgin Islands has one dominant utility (the Water and Power Authority) and a similar climate to Hainan's. WAPA currently faces a peak load of $140 \mathrm{MW}$, split between two unconnected islands.

Using the experiences of these two regions, we identified some conservationbased DSM programs that were likely to be cost-effective in Hainan. We used a 200-MW coal plant as the benchmark for computing benefits in this screening. That coal plant in Hainan was assumed to have a capacity cost of $\$ 2,000$ per kilowatt, employs coal costing $\$ 1.50$ per $10^{6}$ Btus, has a heat rate of 11,000 Btus per $\mathrm{kWh}$, and variable O\&M costs of $\$ 6.00$ per MWH. We then compared these costs with the (estimated) costs of running various DSM programs. The costs of those programs were based on out-of-pocket expenditures on ihe various measures and their assurned penetration rates. Again, these values were based on the experiences of Jamaica and the U.S. Virgin Islands. If the benefits were greater than the costs, the resource "passed" this gross, presecreening. While an explicit study of Hainan would be necessary to determine which DSM measures were appropriate and what the savings would be, this exercise provides a crude indication of what might be expected there.

The conservation supply curve shown in Figure 4 characterizes the approach used in the study. Any DSM program that we estimated to have a cost of conserved energy less than the avoided cost of Hainan's power system was considered costeffective. The conservation supply curve is "lumpy," of course, because the energy savings of DSM programs are discrete, rather than continuous.

In Table 5, we summarize the estimated results for the year 2000. That year is convenient for two reasons. First, if implemented in the next couple of years, most of the DSM programs considered here would be approaching maximum penetration by then. For example, a residential lighting program would take approximately five years from its initiation to reach maximum penetration. Second, the Hainan government has forecasted electricity demand levels by consuming sector for the year 2000 in its most recent planning exercise. We use these levels as the reference from which savings are estimated. The $\%$ savings column for each of the programs in the table indicates the estimated percentage reduction in consumption for each of the end uses. The total for each of the sectors and the Hainan total, of course, are weighted averages of the end uses. The GWh savings column represents the estimated energy saved from implementing the programs. 
Figure 4

Cost-Effective DSM Options

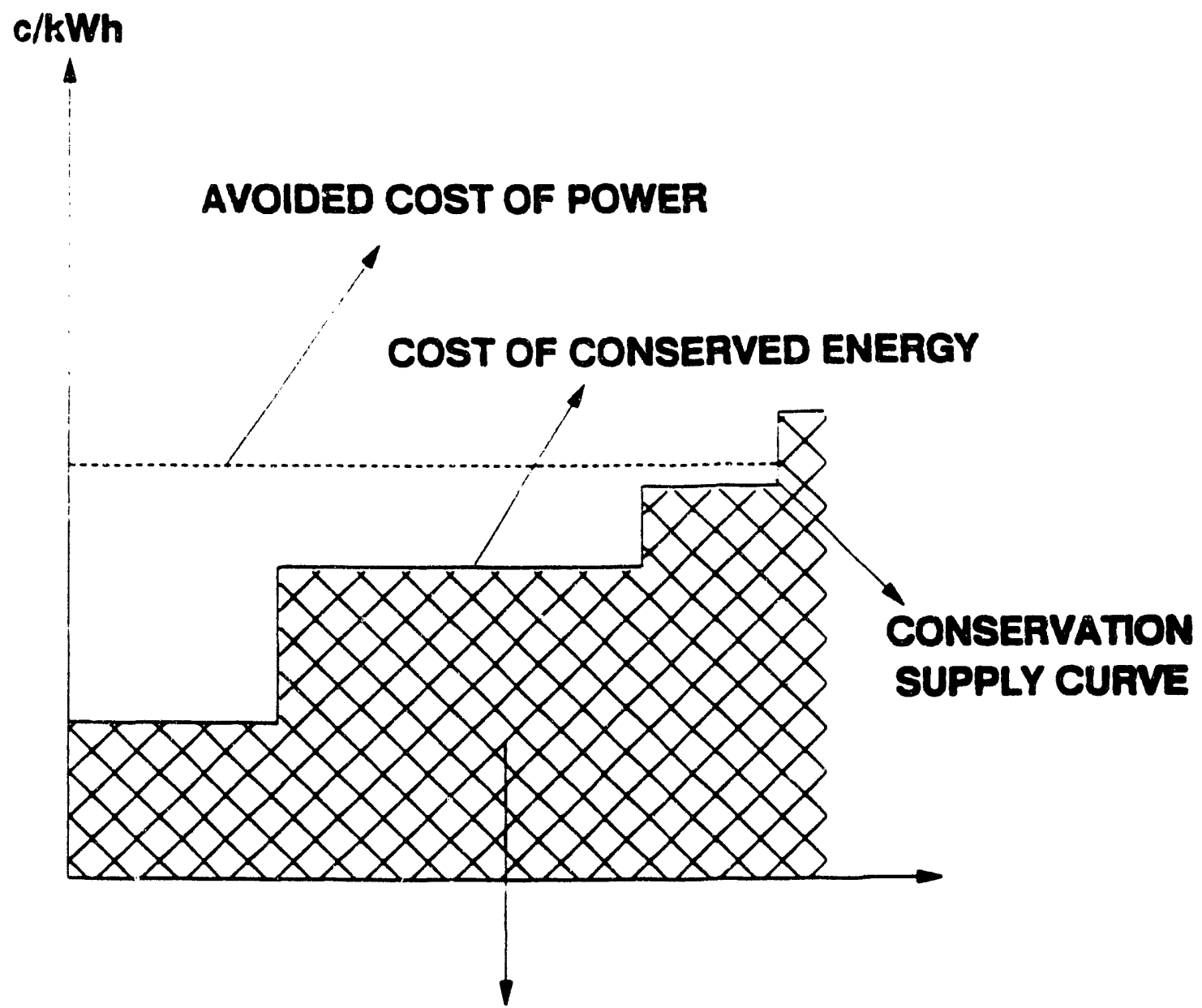

COST-EFFECTIVE DSM PROGRAMS

The results indicate a significant savings from implementing these DSM programs. In total, $1,139 \mathrm{GWh}$ of energy are estimated to be saved. Assuming a 0.6 load factor, that savings represents 217 MW of capacity, nearty 80 percent of Hainan's current peak load. Most of the savings are estimated to be in the industrial sector because of the large percentage of Hainan's electricity consumption attributable to industrial users. The reason for this large percentage is the high rate of industrialization anticipated by the planners over the next eight years. We conservatively estimate that 20 percent of forecasted industrial consumption can be si ved through conservation measures such as efficient lighting and air conditioning. 


\begin{tabular}{|c|c|c|}
\hline \multicolumn{3}{|c|}{$\begin{array}{c}\text { Table } 5 \\
\text { Indication of Possible Energy Savings } \\
\text { from Conservation Programs } \\
\text { By Consuming Sector } \\
\text { Hainan, China } \\
2000\end{array}$} \\
\hline $\begin{array}{l}\text { Sector/ } \\
\text { Program }\end{array}$ & $\begin{array}{c}\% \\
\text { Savings }\end{array}$ & $\begin{array}{r}\text { GWh } \\
\text { Savings }\end{array}$ \\
\hline $\begin{array}{l}\text { Residential } \\
\text { Solar Water Heating } \\
\text { Efficient Lighting } \\
\text { Cooling }\end{array}$ & $\begin{array}{l}40 \\
40 \\
20\end{array}$ & $\begin{array}{l}30 \\
50 \\
23\end{array}$ \\
\hline Total & 25 & 103 \\
\hline $\begin{array}{l}\text { Commercial } \\
\text { Efficient Lighting } \\
\text { Cooling } \\
\text { Refrigeration }\end{array}$ & $\begin{array}{l}70 \\
10 \\
5\end{array}$ & $\begin{array}{r}120 \\
34 \\
8\end{array}$ \\
\hline Total & 25 & 162 \\
\hline $\begin{array}{l}\text { Industrial } \\
\text { Conservation }\end{array}$ & 20 & 873 \\
\hline Hainan Total & 21 & 1,139 \\
\hline
\end{tabular}

SOURCE: Authors' estimates.

Again, the results in Table 5 do not exhaust all of the DSM or efficiency-enhancing possibilities. The data are merely indicative of what is possible. For one thing, we considered only conservation programs; load management programs were not considered. And, load management programs can be powerful tools to shave peak load and thereby avoid constructing and operating costly peaking units. Second, because of data limitations, we did not consider behavioral DSM strategies such as cost-based electricity pricing. Finally, we did not consider improving the physical efficiency of the power delivery system.

In the next three sections, we explore these DSM options in more detail, including the ones that we were not able to provide quantitative estimates for (e.g., electricity 
pricing). The discussion provides descriptions of the technologies, potential technical savings from implementing the programs, and, in some cases, mechanisms for implementing the programs (e.g., utility financing, customer financing). 


\section{TECHNICAL DSM MEASURES}

\subsection{BUILDING STANDARDS}

More stringent energy conservation building standards in the three rapidly growing cities of Haikou, Sanya, and Yang Pu could save significant amounts of energy. These cities are currently experiencing a construction boom and every indication is that it will continue to do so in the future. Therefore, this is a particularly favorable time to implement conservation standards for new commercial construction. Currently, Chinese national standards are used. These standards are not as stringent as those used in the West. The recently developed standards for Jamaica may be a good reference point for Hainan authorities because Jamaica and Hainan have similar climates (Jamaica Bureau of Standards, 1992).

\subsection{SECTORAL MEASURES}

\subsubsection{Households}

Generally speaking, lighting programs replacing incandescent with fluorescent bulbs are among the most cost-effective DSM measures for any sector. That should be no different in Hainan. Developing an effective lighting program in Hainan, however, depends on a number of factors. For example, it depends on whether or not lighting is part of the building conservation standards. As with other DSM programs, another factor is the type of market the program is designed for: single units or multiple families.

A program to increase the penetration of efficient lighting in Hainan could achieve rapid and significant demand-side energy savings for the Electricity Bureau while lowering energy costs for household customers. In Jamaica, for example, the authorities believe that they can save 60 percent of the electricity used for lighting with a direct-install lighting program (Conservation Law Foundation, 1990). In the U.S. Virgin Islands, with nearly 37,000 households consuming on average $350 \mathrm{kWh}$ per year for lighting, the savings for this program approaches 6,000 MWh per year for islands with a population of only 110,000 (Hill, Chronowski, and Shapiro, 1992).

There are many different energy-efficient compact fluorescent bulb and ballast combinations that could be used in Hainan. Selection could be made on a house-byhouse basis to provide the required amount of lighting and to fit existing fixtures. An example would be to replace incandescent bulbs with ballasts with screw-in adapters so that lighting fixtures would not have to be replaced. In cases in which screw-in replacements are not appropriate, fluorescent fixtures would be used as replacement lighting.

Although the initial cost of energy-efficient fluorescents is significantly higher than their incandescent counterparts, a fluorescent bulb will outlast 13 incandescents. Because of the high up-front costs, however, the program inust be made attractive to individual customers. One possibility is to provide the lights at no cost to customers. And, because it is difficult for the average customer to identify the appropriate lighting retrofits, the program should be implemented through a direct installation program. In this 
program, representatives of the Electricity Bureau would visit customers' homes and install the appropriate lighting retrofits in high-use locations where it is acceptable to the customer.

The other two conservation measures listed in Table 5 for households are air conditioning and solar water heating. The former is discussed under commerce in Section 4.2.2. and the latter is discussed in Section 6 under renewable options.

\subsubsection{Commerce}

Given current conditions in Hainan, there are a number of possibilities to improve the efficiency of room and small central air conditioners used in both residential (thought to be limited at the present time) and commercial buildings, which can cost-effectively reciuce electricity consumption by a significant amount. The first is to establish progressive performance standards for new room and small central air conditioners that are sold and/or imported into Hainan. This results in a phase-in time for the air conditioners to reach the maximum technical potential of energy efficiency. Another way would be to provide financial incentives to customers purchasing efficient models. Finally, energy-efficient air conditioners could be part of the new building codes. The potential savings are significant. In the U.S. Virgin Islands, for example, it was estimated that the technical savings from an air-conditioning program is about 12.5 percent per unit. For central air conditioners consuming approximately 11,500 kWh per year, the savings per unit are 1,437 kWh per year (Hill, Chronowski, and Shapiro, 1992).

Based on experiences throughout the world, lighting programs in the commercial sector are even more financially attractive for electric utilities than those implemented in the household sector. There is every reason to believe that this will be the case in Hainan. Again, specifics of any program in Hainan depend on whether efficient lighting is made part of the building codes. Like all energy-using durables, it is more difficult to develop incentives for commercial building owners to replace existing incandescents than it is to mandate the use of fluorescents through building codes. In Jamaica, a program to replace existing incandescent bulbs with fluorescent ones is estimated to save the electric firm 34,000 MWh per year (Conservation Law Foundation, 1530).

\subsubsection{Industry}

This program would target the largest users of electricity in industry. In terms of relieving electric generating capacity requirements, this group tends to give the largest payback because these conservation measures extend beyond lighting and cooling to industrial processes. Included in the industrial process category are electric motors which are among the highest users of electricity in industry. In the United States, for example, electric motors account for nearly 70 percent of industrial electricity consumption.

Industries in this largest user group tend to operate multiple shifts. Therefore, they have a high load factor (peak to average electricity use). Therefore, conservation measures reduce system load during all hours of the day. Some industrial users also generate large amounts of steam for thermal processes. 
An example of a program targeting industrial users would provide energy studies for each facility and, where necessary, provide installation assistance. To promote the greatest degree of participation, financial incentives may be required by the Electricity Bureau. A typical program operates in the following manner. Engineers familiar with the equipment and operating procedures of each industry conduct energy studies on each facility. At sites where waste products are available for generating steam to drive turbines, these studies examine the cogeneration feasibility. The economics of cogeneration facilities are good, especially if the fuel is currently a waste product.

The studies will go on to identify efficiency improvements in all systems using electricity: motors, electrolytic cells, pumps, fans, conveyors, mixers, ventilation equipment, and the like. Based on this assessment, a list of cost-effective efficiency measures is developed for each facility.

There are various mechanisms for ensuring that cost-effective measures are implemented by each of the facilities. For example, the Electricity Bureau could share installation costs so that the owners/managers of the facilities experience a short payback period for their up-front investment costs. The threshold payback could be set as low as 12 months. Another example of an implementation mechanism is to provide construction management services for facilities where the in-house staff is not capable of this activity.

The cost-effectiveness of programs of this type have been demonstrated throughout the world. For example, based on an analysis of 13 major industrial firms and the electric utility in Senegal, the World Bank (UNDPWorld Bank, 1983) estimated that 63,000 tonnes of oil equivalent could be saved there through conservation measures. One-half of this amount could be saved with investments totaling $\$ 16$ million, and with pay-back periods of three years or less. In Morocco, the World Bank (UNDPMorld Bank, $1984 a$ ) estimated that an investment of $\$ 38.5$ million in conservation measures would save industrial users of energy $\$ 16.5$ million in 1981. In a comprehensive study of the industrial sector in Thailand, it was estimated that 12 percent (3.7 million BCOE/year) of energy use could be saved through cost-effective conservation measures (Desai and Nyman, 1986). Of the total savings, one-half would be derived from industrial process improvements and the other half from housekeeping and new equipment. In the Philippines, industrial conservation potential was estimated to be nine million barrels per year-or 18 percent of total industrial energy use in 1980 (Desai and Nyman, 1986). Approximately 70 percent of this energy savings potential has payback periods of less than two years.

\subsubsection{Transportation}

A good example of demand-side management activities outside of the power sector is automobile traffic management in the cities of Haikou and Sanya and the Yang Pu area. The capital city Haikou has grown rapidly in the past two years and continues to grow without any mass-transit plans or plans for automobile traffic management. The same can be said for the "special" special economic zone in Yang Pu and the tourist city of Sanya. It is an opportune time for planning authorities in Hainan to consider methods to manage that demand for both environmental and financial reasons before any large- 
scale transportation infrastructure expenditures are committed.

Transportation accounts for a large share of petroleum product consumption in Hainan. There is a potential for significant energy savings and a range of options for capturing those savings. The options include:

- optimizing the use of public transport systems;

- improving traffic flow;

- fuel-switching;

- using the tax system to discourage certain types of vehicle use;

- improving vehicle efficiency through proper maintenance;

- improving the road infrastructure;

- driver training; and

- improving management techniques for both private firms and public transport scheduling.

Here again, examples of cost-effectiveness traffic management options abound throughout developing regions. In Niger, for example, a private transport firm reduced its fuel consumption per kilometer by 22 percent over the 1977-1981 period through a program of vehicle modernization and driver training in fuel efficiency (UNDPMorld Bank, 1984b). A program of traffic management in Kingsion, Jamaica saved three percent of annual fuel use (UNDPMorld Bank, 1985a). Similarly, a study of traffic flow in a small part of Bangkok showed that an automatic traffic control system could result in fuel savings of up to 20 percent (UNDPNorld Bank, 1985b). In Senegal, a study of the transport sector showed that approximately 26,000 tonnes of oil equivalent could be saved through various management and infrastructure improvements (UNDPMorld Bank, 1983). In Costa Rica, a demonstration study showed that low-cost, quick payback measures (improved maintenance procedures and driver training) could have a significant impact on fuel use. Improved maintenance procedures for taxi and bus fleets led to energy savings of 1.8 percent and 6.5 percent, respectively. The corresponding percentage savings resulting from driver training were 15.1 percent and 4.2 percent (Sabadell, Greene, and Erickson, 1986). 


\section{A BEHAVORAL DSM STRATEGY: ELECTRICITY PRICING}

\subsection{THE CURRENT STUATION}

The philosophy behind the current tariff in Hainan is to encourage electricity consumption because of excess generating capacity. The tariff is presented in Table 6 . Hainan's generating capacity is very lumpy with over-sized units not allowing load to be followed very easily. Because of the lumpy excess capacity, far-sighted price incentives are not in place to encourage electricity conservation over the longer-term. That is, the Hainan Electricity Bureau faces the classic short run-long run pricing problem confronting many other utilities throughout the world: pricing for excess capacity in the short run, but distorting incentives for the longer term because economic development is promoting electricity demand growth rates so large that the utility will be experiencing capacity shortages in the longer term. And, making up that electricity generation capacity deficit is very costly because of the capital intensity of electric generating systems.

\begin{tabular}{lccc}
\hline & $\begin{array}{c}\text { Table 6 } \\
\text { Current Electricity Tariffs } \\
\text { Hainan, China } \\
\text { (in Cents per kWh) }\end{array}$ & \\
\hline Sector & $12-6$ am & 6 arn-7 pm & 7-Midnight \\
& & & \\
\hline Residential & 5.7 & 5.7 & 5.7 \\
Commercial & 4.3 & 8.5 & 8.5 \\
Industry & 4.3 & 6.6 & 6.6 \\
Agriculture & 4.3 & 4.7 & 4.7 \\
& & & \\
\hline
\end{tabular}

SOURCE: Hainan Electricity Bureau.

"Based on an exchange rate of 5.3 Yuan per U.S. dollar.

\subsection{FUTURE POSSIBIUTIES}

Cost-based electricity pricing is a powerful tool to (i) generate financial resources for the electric power sector and (ii) manage electricity demand. The "economic miracle" in South Korea, for example, was supported by a corresponding increase in electric generating capacity in a relatively short period of time. South Korea is a good example of a country with little indigenous energy resources (i.e., some low-grade anthracite coal and hydropower) and large commitments of capital to export-oriented industries. It used electricity pricing and related initiatives to provide resources for its power sector during its formative stages of development from 1961-1973 (Hill, 1992a). Generating capacity 
increased nearly 12-fold in a 12-year period during the 1961-1973 period and more than 50-fold from 1962 to the present time. The Korean experience is a good example of the contribution of pricing-related initiatives to development of the power sector. Besides setting prices at a level sufficient to provide resources for the power sector, a number of initiatives designed to reduce the cost of electricity supply were implemented. These pricing-related initiatives were a significant source of resources for the power sector during the $1962-73$ period. More recently, implementation of time-of-day pricing and enactment of legislation aimed at improving the performance of public enterprises significantly contributed to the efficiency of the power system.

Using electricity pricing as a DSM strategy is a behavioral complement used by Western utilities as part of their DSM strategy. It can be used both by itself and as a financial incentive for other demand-side measures (Hill, 1990, 1991 a).

As a means to influence the pattern of electricity demand, the most widely adopted pricing strategy by Western utilities is time-of-use (TOU) pricing, which generally refers to electricity rates which vary over the course of a year: hour-by-hour, day-by-day, or season-by-season (Hill, 1990). Time-of-day (TOD) pricing (rates which vary over the course of a day), a specific form of the general class of TOU rates, has generally been effective in shifting electricity consumption from peak to off-peak periods. And, at least for higher volume users (high-volume residential and higher-voltage commercial and industrial users), it has proven to be cost-effective in the United States. Western utilities have also used another form of a TOU tariff, an interruptible or curtailable (I/C) one, to reduce demand on days when capacity utllization is approaching its limit, usually offering rate incentives to large-volume, high-voltage consumers in return for shedding load for a limited amount of time on short notice. From every indication, these tariffs have been successful in reducing both U.S. and Western European capacity requirements.

In the immediate future, time-of-day pricing would not seem to be cost-effective for the residential sector in Hainan. For that pricing structure to be cost-effective, average consumption levels should be around $1200 \mathrm{kWh}$ per month, typically caused by the penetration of air conditioners and swimming pools (Hill, 1991C).

There does seem to be room to implement cost-effective innovative pricing schemes in the industrial sector, however. Even though the best available evidence suggests meager kWh shifting from peak to off-peak periods for U.S. industrial consumers as a whole upon introduction of TOD rates--on the order of one percent--two important factors must be considered (Hill, 1991b). First, over the longer term, after firms have time to make adjustments in their industrial processes in response to the tariff, response to TOD rates will be more substantial. Second, evidence from both the U.S. and Western Europe shows that industrial responsiveness is highly variable by industry.

From the standpoint of developing regions, this latter consideration is important. Since the composition of the manufacturing sector in Western economies is not representative of that found in Hainan, a properly designed TOD tariff for Hainan can probably elicit a larger response than that exhibited in industrialized countries. As an illustration, cement production is a large and important industry for infrastructural development in many developing countries, accounting for as much as 30 to 40 percent 
of national commercial energy consumption. That should be the case for Hainan. And, cement production generally shows the largest short- and long-run response to TOD rates in Western economies. Also, in many countries in which power availability and reliability concerns have forced many manufacturers to develop their own power sources, the Western experience shows that these manufacturers are some of the most responsive to TOD rates. Another form of TOU pricing which has widespread applicability in the developing world is an interruptible/curtailable rate, having proved effective in reducing high-voltage load on system peak days for Western utilities and reducing capacity requirements (Hill, 1991b). That pricing structure should also be investigated for its applicability to Hainan. 


\section{RENEWABLE RESOURCE OPTIONS}

\subsection{SOLAR WATER HEATING}

Hainan appears to have the climate to support a cost-effective residential solar water heating program. These programs are cost-effective in regions with similar climates such as Jamaica (Conservation Law Foundation, 1990) and the U.S. Virgin Islands (Hill, Chronowski, and Shapiro). The most effective types of programs are based on point of sale. That is, the program targets customers who are replacing old water heaters or are purchasing ones for the first time.

A number of different types of systems are feasible, ranging from the simple to the relatively more complex and expensive. One is a simple gravity circulation system with a single collector and an insulated tank in an integrated housing. The more elaborate systems have multiple solar collectors with an indoor storage tank, pump, and control, and back-up electric heating.

The Electricity Bureau could use a number of different financing and promotion mechanisms for this program. One would be to subsidize local solar water heater manufacturers to reduce the retail price of units to be competitive with other types of water heaters. Another would be to finance the price difference between a solar water heater and other types with no financing costs for buyers. Another method would be to pay the total cost of installing solar water heaters.

The cost-effectiveness of a program of this type for the Electricity Bureau depends, of course, not only on the financing method chosen, but also on the market penetration of the solar heaters. Lacking data on the potential market in Hainan, it is not possible to estimate with precision the cost-effectiveness of the program. However, the Jamaican program has an estimated benefit-cost ratio of 2.37 (Conservation Law Foundation, 1990). The corresponding ratio in Hainan awaits further study, including the potential market for the heaters. Designing a program for the optimal market penetration of solar water heating depends on the type of housing. For example, a program for decentralized single-family ownership of housing would differ from one targeted at public housing.

\subsection{WIND POWER}

At present, there is one grid-connected wind farm with $55 \mathrm{~kW}$ maximum capacity, located in the southern portion of Hainan. Wind-based electricity generation may be costeffective on other portions of the Island. Although it was indicated that other spots on the Island have been metered, the team did not have access to that data, nor were they sure that these other metered spots were optimal ones. We recommend that wind energy be looked at in greater detail as part of the IRP effort.

This recommendation is based on data obtained from other experiences throughout the world and U.S. cost standards. The key points to keep in mind for gridconnected, wind generation are that reliability is increasing with experience at the same time that the capital and O\&M costs are declining. Problems with wind in other regions, such as land availability and its cost, do not seem to be a problem in Hainan. 


\section{RECOMMENDATIONS}

In this study, we suggested some alternatives to constructing and operating coalfired electric generating plants to satisty future electric energy and load requirements in Hainan. However, because of time and data limitations, the economic attractiveness of the suggested alternatives were not based on a rigorous comparison of their costs and benefits. Rather, they were based on a rough estimate, using a coal-fired power plant as the avoided generating unit and the experiences of other regions to estimate the potential savings from these DSM options. We also did not quantify the environmental and macrosconomic external benefits associated with not constructing and operating coal generating units. Finally, the effects of some other attractive DSM strategies such as electricity pricing were also not quantified. Therefore, the study was indicative--pointing out evaluation approaches and suggesting options--rather than definitive.

Resulting from this, the primary recommendation is that the DSM and renewable supply options identified in the study be examined in much greater detail, not only to verify their cost-effectiveness, but also to identify other economically attractive options. The recommended study would extend beyond using coal as the avoided unit in determining the benefits of an optio?. With the expectation that more natural gas may be found off Hainan's coast, it is possible that the avoided unit will be a gas-fired one. To systematically assess these options, the principles of integrated resource planning (IRP) should be applied.

A full cycle of comparing DSM and supply options (i.e., engaging in the integrated resource planning process), procuring the DSM technologies (i.e., either developing the capability to produce them in Hainan or importing them), and implementing the DSM programs would prepare Hainan for outreach activities in mainland China and other Southeast Asian countries. In fact, we recommend that these management techniques and technology applications be institutionalized as part of Hainan's development strategy. The mechanism for accomplishing this could be a Center for Export Technologies.

Each of these recommendations will be discussed in turn.

\subsection{INTEGRATED RESOURCE PLANNING}

Three types of activities should be pursued to develop the Hainan Electricity Bureau's and 'he government of Hainan's capability to properly compare DSM and supply resources:
- Training,
- Information gathering,
- Resource comparison.

\subsubsection{Training}

It would be beneficial to have two separate levels of training: one at the executive level and the other for staff members of the Electricity Bureau and other government ministries. The executive presentation should last a day or so and should include an 
overview of the two components of the IRP process--least-cost planning and demand-side management--and how they are used together as an analytical tool. The benefits to Hainan from achieving lower cost provision of electricity services should be identified, and their prospective magnitudes presented so that decisionmakers can understand the potential contribution IRP could make to achieving their goals. The presentation should also include a discussion of the social costing of resources. It should also include the experience of developing and developed world utilities with IRP: motivation for IRP, reporting requirements, the extent of usage, and the benefits obtained from its use. Ideally, there would be several speakers at the session, representing both international experience and the Chinese situation.

The second level of training should proceed in two phases. Once the IRP process is adopted, there shnuld be an intensive series of sessions on detailed aspects of its implementation. These sessions should be attended by the practitioners and their managers, rather than executives. This portion of the training would require approximately one week, and again include both Chinese and foreign experts. The training should be organized around four topics:

- Industrial Structure of Electric Power

Under this topic, the industrial organization of electric utilities would be introduced. The discussion would include why electric firms differ from other producers in a market-based economy and various theories of their regulation. A discussion of various types of ownership of electric firms would also be included (i.e., nationally owned as a government department, nationally owned as a stock company, regionally owned, and investor-owned) with their advantages and disadvantages.

- Least-cost planning

This session would discuss conceptual and pragmatic issues in analyzing the eptimal mix of supply resources.

- Demand-side management

This session would cover three areas: (1) methods to develop DSM programs, including data requirements; (2) the process of implementing DSM programs; and (3) the process of evaluating DSM programs.

- Social costing of resources

The environmental (and other) externality debate is introduced in this session. The discussion includes the types of approaches that can be used to incorporate externalities into decisionmaking, along with the experiences of electric firms in other parts of the world. 
- Integrated resource planning

This portion will cover two areas: (1) existing models to compare DSM and supply resources and (2) important factors to consider when comparing them, including differences in their financial, economic, and reliability characteristics.

\section{- Conservation Technologies}

This portion of the training would introduce the engineering aspects of energyefficiency improvements, including the types of off-the-shelf technologies that are currently available and the energy savings likely to result from their use.

In the second phase of this portion of the training, mini-training sessions should be periodically held on complicated aspects of the integrating process for those involved in such complicated areas as DSM program development, resource integration, and the like.

\subsubsection{Information Gathering}

In Section 3.1, we pointed out the type of data needed to conduct a study of the sort proposed here and to design, implement, and evaluate DSM programs. Ideally, it should include data on electricity consumption by end use (i.e., lighting, refrigeration). However, that and other types of data needed to develop DSM programs are not routinely collected by government agencies or electric utilities. One of two methods can be used to collect end-use data. First, customers can be metered to accurately quantify end-use consumption. Lacking funds to accomplish this, the second method is to conduct a survey of electricity customers. Data are also needed on the customer base of the programs. How many potential customers will particpate in a commercial lighting programs? A residential solar water heating program? Data is also required on the resource base for the renewable supply options suggested for consideration in this study. It may be the case that additional wind metering may have to be undertaken.

Besides quantities, many other types of information are required. Many of them relate to the institutional structure of Hainan. For example, information on the possibility of using different financing mechanisms for DSM programs is required. The ownership of the housing stock must also be factored in.

This iniormation-gathering activity should use Chinese institutions to the maximum extent possible. A good example is the South China Environmental Research Institute which has historical data on Hainan. Also, staff of the ministries in Haikou should be actively involved, including the newly created Office of Conservation. Chinese students seeking advanced degrees are another important staffing source.

\subsubsection{Resource Integration}

The third activity is the heart of the process: resource comparison. The activity involves procuring and adapting a model to systematically assess the different financial, economic, and reliability dimensions of DSM and supply resources. The outcome of the 
process wou!d be a plan or strategy for employing resources in the future. Thisre should be a short-term action plan produced which requires the immediate attention of the Electricity Bureau and other policymakers. The second output of the process is a longterm integrated resource plan spanning a 15- to 20-year period. This plan provides a resource road map for policymakers.

Changing conditions external to the Electricity Bureau (e.g., changing fuel input prices, electricity demand growth rates, and the costs of financing) suggest that IRP is not a one-time study, but rather a continuing process. An appreciable change in any one of these variables can alter the relative cost-effectiveness of resources. Recognizing the dynamics of this process, another recommendation is that IRP be institutionalized at the Electricity Bureau. One method is to have regular plan updates. For example, a common practice with U.S. utilities is to perform a full-scale, integrated resource plan every three years. However, in the intervening two years, the utilities are required to update the plan based on changing external circumstances.

Because IRP is a continuing process, we also recommend that changes be made in the organizational structure of the Electricity Bureau to accommodate the process. One approach used in the United States is to organize around the IRP process using a feam concept, drawing upon appropriate staff from all departments within the utility. The center of the process, an integration team, takes input from a demand-side team and a supply-side team. The integration team is ultimately responsible for developing the integrated plan.

\subsection{CENTER FOR EXPORT TECHNOLOGIES}

If implemented and followed through properly, two things should result from this planning activity: (1) development of a management capability in integrated planning and (2) use of more energy-efficient durable goods. We recommend that the Hainan planners use these two outcomes as a cornerstone for an export strategy related to energy efficiency. The strategy here would be to develop a coordinating mechanism--such as a Center for Export Technologies--that could promote the exports of both a management technique (i.e., IRP) and energy-efficient technologies tailored for mainland China and other Southeast Asian countries. Those technologies could be produced in Hainan and the industry promoted as part of the government's overall development strategy. 


\section{REFERENCES}

California Public Utilities Commission and California Energy Commission, Standard Practice Manual: Economic Analysis of Demand-Side Management Programs, December 1987.

Conservation Law Foundation, 1990, Power by Efficiency: An Assessment of Improving Electrical Efficiency to Meet Jamaica's Power Needs, June.

Desai, V.V. and Kari Nyman, 1986, "Industrial Energy Conservation: Notes on Three Country Studies," Presented at the Asia and Near East Workshop on Energy Conservation and Private Power Generation, Bangkok, Thailand, September 29-October 3.

Environmental Resources, Lid., 1991, Management of the Environment and Natural Resources in Hainan Province.

Gettings, Michael, Eric Hirst, and Evelin Yourstone, 1991, Diamond: A Model of Incremental Decision Making for Resource Acquisition by Electric Utilities, Oak Ridge National Laboratory, Oak Ridge, Tennessee, ORNL/CON-315, February.

Henry, Donald Putnam, 1991, "Restructuring Hainan's Fiscal System," RAND Corporation, Santa Monica, California.

Hill, Lawrence J., 1990, Electricity Pricing as a Demand-Side Management Strategy: Western Lessons for Developing Countries, Oak Ridge National Laboratory, Oak Ridge, Tennessee, ORNL-6620, December.

Hill, Lawrence J., 1991a, "Can Developing Countries Benefit from Innovative Pricing in the Power Sector?," Natural Resources Forum, 15(1), pp. 15-25, February.

Hill, Lawrence J., 1991b, "Large Power Users and Capacity Shortages in Duveloping Countries: The Role of Innovative Pricing," International Journal of Global Energy Issues, 3(2), pp. 86-96.

Hill, Lawrence J., 1991c, "Residential Time-of-Use Pricing as a Load Management Strategy: Effectiveness and Applicability," Utilities Policy, 1(4), pp. 308-318, 1991.

Hill, Lawrence J., 1992a, "Pricing Initiatives and Development of the Korean Power Sector: Policy Lessons for Developing Countries," Energy Policy, 20(4), pp. 344-354, April.

Hill, Lawrence J., 1992b, "Integrating Methods and Resource Selection in Electric-Utility Planning," Utilities Policy, Forthcoming.

Hill, Lawrence J., Robert Chronowski, and Andrew M. Shapiro, 1992, An Integrated Assessment of Electric Power Resource Options in the U.S. Virgin Islands, Oak Ridge National Laboratory, ORNLTM-12186, Oak Ridge, Tennessee, Forthcoming. 
Hill, Lawrence J., Eric Hirst, and Martin Schweitzer, 1991, Integrating Demand-Side Management Programs into the Resource Plans of U.S. Electric Utilities, Oak Ridge National Laboratory, Oak Ridge, Tennessee, ORNL/CON-311, January (aiso published by the Electric Power Research Institute, Palo Alto, California, EPRI TR-100255, December 1991).

Hill, Lawrence J., Eric Hirst, and Martin Schweitzer, 1992a, "From DSM Technologies to DSM Programs: Issues in Demand-Side Planning for Electric Utilities," Energy, The International Journal, 17(2), pp. 151-160.

Hill, Lawrence J., Eric Hirst, and Martin Schweitzer, 1992b, "The Process of Integrating DSM and Supply Resources in Electric Utility Planning," Utilities Policy, 2(2), pp. 100-107, April.

Hill, Lawrence J., Eric Hirst, and Martin Schweitzer, 1992c, "How Electric Utilities Plan Demand-Side Management Programs," Strategic Planning for Energy and the Environment, 2(4), pp. 23-34, Spring.

Jamaica Bureau of Standards, 1992, Jamaica National Building Code: Energy Efficiency Building Code, EEBC-92, Kingston, Jamaica, February.

Lotus Consulting Group, 1988, UPlan, The Electric Utility Planning System, Los Altos, California.

Perlack, R.D., J.W. Ranney, and M. Russell, 1991, Biomass Energy Development in Yunnan Province, China: Preliminary Evaluation, Oak Ridge National Laboratory, Oak Ridge, Tennessee, ORNL/TM-11791, June.

Perlack, R.D., M. Russell, and Zhongmin Shen, 1991, "Energy and Environmental Policy in China," Annual Review of Energy, pp. 205-33.

Policy Planning Associates, 1991, SAFEPLAN (Scenario Analysis Framework for Expansion Planning): Users' Manual, Kirkland, Washington.

Roll, Charles Robert, 1991, "A Comparison of Hainan with the Other Special Economic Zones," RAND Corporation, Santa Monica, California.

Sabadell, Alberto J., David L. Greene, and Jeffry J. Erickson, 1986, "Transportation Energy Conservation," Presented at the Asia and Near East Workshop on Energy Conservation and Private Power Generation, Bangkok, Thailand, September 29-October 3.

Schweitzer, Martin, Eric Hirst, and Lawrence J. Hill, 1991, Demand-Side Management and Integrated Resource Planning: Findings from a Survey of 24 Electric Utilities, Oak Ridge National Laboratory, Oak Ridge, Tennessee, ORNL/CON-314, Forthcoming.

Temple, Barker, and Sloane, 1988, Multiobjective Integrated Decision Analysis System (MIDAS), Vol. 1: Model Ovenview, Electric Power Research Institute, Palo Alto, California, EPRI P-5402, Apri!! 
UNDPMorld Bank, 1983, Senegal: Issues and Options in the Energy Sec-tor, Washington, D.C., Report No. 4182-SE, July.

UNDPNorld Bank, 1984a, Morocco: Issues and Options in the Energy Sec-tor, Washington, D.C., Report No. 4157-MOR, March.

UNDPMorld Bank, 1984b, Niger: Issues and Options in the Energy Sector, Washington, D.C., Report No. 4642-NIR, May.

UNDPMorld Bank, 1985a, Jamaica: Issues and Options in the Energy Sec-tor, Washington, D.C., Report No. 5466-JM, April.

UNDPMorld Bank, 1985b, Thailand: Issues and Options in the Energy Sec-tor, Washington, D.C., Report No. 5793-TH, September.

Wolf, Charles, 1991, "Restructuring Hainan's International Trade and Finance: Currency, Foreign Exchange, and Trade," RAND Corporation, Santa Monica, California.

Yeh, K.C., 1991, "The Lessons of East Asian Development and Alternative Development Strategies for Hainan," RAND Corporation, Santa Monica, California. 


\section{INTERNAL DISTRIBUTION}

1-20. K. R. Ballow

21. D. R. Baumgardner

22. V. D. Baxter

23. B. L. Bush

24. W. Fulkerson

25. P. S. Gillis

26-45. L. J. Hill

46. E. L. Hillsman

47. C. R. Kerley

48. M. A. Kuliasha

49. R. Lee

50. V. C. Mei
51. R. D. Perlack

52. D. E. Reichle

53-72. M. Russell

73. R. B. Shelton

74. B. Sorensen

75. D. P. Vogt

76. T. J. Wilbanks

77. ORNL Patent Otfice

78. Central Research Library

79. Document Reference Section

80-82. Laboratory Records

83. Laboratory Records-RC

\section{EXTERNAL DISTRIBUTION}

83-102. William F. Barron, Coordinator, Graduate Program in Environmental Management, University of Hong Kong, Pokfulam Road, Hong Kong

103. Ronald Bowes, Office of Technical Assistance, Office of Conservation and Renewable Energy, U.S. Department of Energy, CE-54 Forrestal Building, 1000 Independence Ave., S.W., Wahington, DC 20585

104. B. G. Buchanan, Computer Science Department, University of Pittsburgh, 206 Mineral Industries Building, Pittsburgh, PA 15260

105. H. M. Ingram, Director, Udall Center for Studies in Public Policy, University of Arizona, 803/811 East First Street, Tucson, Arizona 85719

106-125. Phil LaRocco, Phil LaRocco Associates, 1133 Avenues of the Americas, Suite 1125, Now York, Now York 10036

126. C. D. MacCracken, President, Calmac Manufacturing Corporation, 101 West Sheffield Avenue, P. O. Box 710, Englewood, New Jersey 07631

127. J. B. Shrago, Director, Office of Technology Transfer, Vanderbilt University, 405 Kirkland Hall, Nashville, TN 37240

128. Frank Stewart, Deputy Assistant Secretary, Office of Technical Assistance, Office of Conservation and Renewable Energy, U.S. Department of Energy, CE-54 Forrestal Building, 1000 independence Ave., S.W., Wahington, DC 20585 
129. Office of Assistant Manager for Energy Research and Development, DOE-ORO, P.O. Box 2001, Oak Ridge, TN 38831-8600

130-149. OSTI, U.S. Department of Energy, P.O. Box 62, Oak Ridge, TN 37831

150-169. Zhongmin Shen, Energy, Environmental, and Resources Center, University of Tennessee, 327 South Stadium Hall, Knoxville, Tennessee 37996-0710 

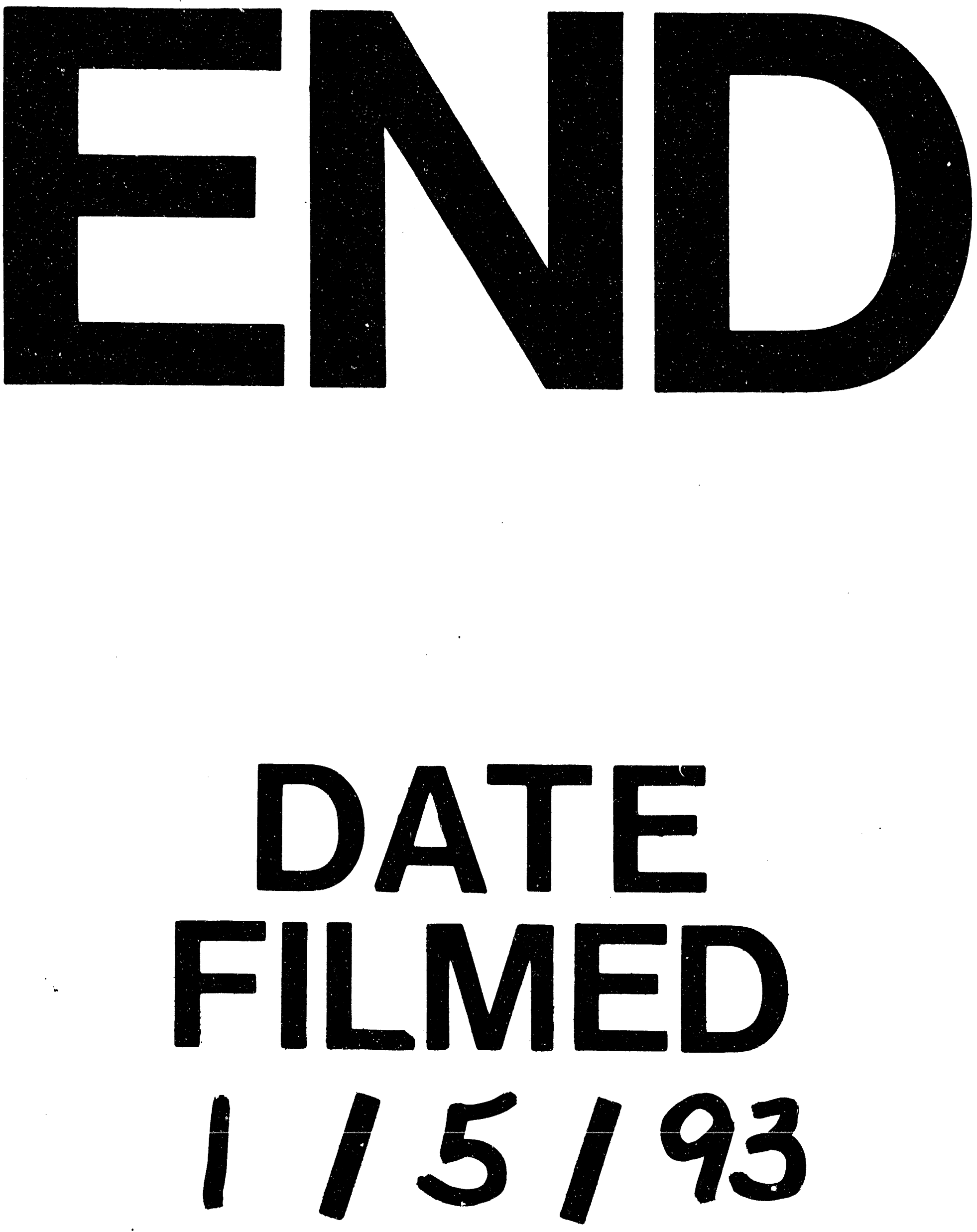

1 


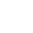

